\title{
Living Benthic Foraminifera from the Surface and Subsurface Sediment Layers Applied to the Environmental Characterization of the Brazilian Continental Slope (SW Atlantic)
}

\author{
Luciana Cristina de Carvalho Santa-Rosa ${ }^{1, *}$, Sibelle Trevisan Disaró ${ }^{1}$, Violeta Totah ${ }^{2}$, Silvia Watanabe ${ }^{2}$ \\ and Ana Tereza Bittencourt Guimarães ${ }^{3}$ (D) \\ 1 Laboratório de Foraminíferos e Micropaleontologia Ambiental, Universidade Federal do Paraná, Avenida \\ Coronel Francisco Heráclito dos Santos 100, Curitiba, Paraná 81530-000, Brazil; stdisaro@ufpr.br \\ 2 Museo Argentino de Ciencias Naturales "Bernardino Rivadavia"-CONICET, Avenida Angel Gallardo 470, \\ Buenos Aires C1405DJR, Argentina; vtotah@macn.gov.ar (V.T.); silviawata.8@gmail.com (S.W.) \\ 3 Centro de Ciências Biológicas e da Saúde Rua Universitária, Universidade Estadual do Oeste do Paraná, \\ Cascavel, Paraná 85819-110, Brazil; anatbguimaraes@gmail.com \\ * Correspondence: carvalho.c.lu@gmail.com
}

check for updates

Citation: Santa-Rosa, L.C.d.C.; Disaró, S.T.; Totah, V.; Watanabe, S.; Guimarães, A.T.B. Living Benthic Foraminifera from the Surface and Subsurface Sediment Layers Applied to the Environmental

Characterization of the Brazilian Continental Slope (SW Atlantic). Water 2021, 13, 1863. https:// doi.org/10.3390/w13131863

Academic Editors: Vincent Bouchet, Fabrizio Frontalini and Daniela Zeppilli

Received: 25 May 2021

Accepted: 25 June 2021

Published: 3 July 2021

Publisher's Note: MDPI stays neutral with regard to jurisdictional claims in published maps and institutional affiliations.

Copyright: (c) 2021 by the authors. Licensee MDPI, Basel, Switzerland. This article is an open access article distributed under the terms and conditions of the Creative Commons Attribution (CC BY) license (https:/ / creativecommons.org/licenses/by/ $4.0 /)$.

\begin{abstract}
Living benthic foraminifera $(>63 \mu \mathrm{m})$ were studied to characterize the continental slope of the Potiguar Basin (SW Atlantic). Foraminifers from the surface $(0-2 \mathrm{~cm})$, subsurface $(2-5 \mathrm{~cm})$, and integrated $(0-5 \mathrm{~cm})$ sediment layers were analyzed to verify their contribution to environmental characterization. It was also estimated if and which changes occur when the subsurface is added. Sampling stations were distributed in five transects in four isobaths (150, 400, 1000, and $2000 \mathrm{~m})$. Sediment samples were fixed with $4 \%$ buffered formaldehyde and stained with Bengal rose. Were recorded 396 species in the surface layer, 228 in the subsurface, and 449 in integrating both layers. This study did not include tubular agglutinated species. The assemblages from $150 \mathrm{~m}$ isobath indicated the upper slope, from $400 \mathrm{~m}$ indicated the middle slope and the ones from the $2000 \mathrm{~m}$ indicated the lower slope. The surface layer's assemblage at $1000 \mathrm{~m}$ isobath was more similar to the middle slope; in contrast, its subsurface layer's assemblage had more similarity with the lower slope. Rarefaction curves, Permanova, and NMDS routines indicated a high resemblance between surface and integrated layers. Therefore, the first two centimeters were sufficient to characterize this region based on living benthic foraminifera.
\end{abstract}

Keywords: living benthic foraminifera; environmental characterization; vertical stratification; continental slope; Potiguar Basin; Rio Grande do Norte

\section{Introduction}

The study of Foraminifera is an important tool for environmental quality assessment, as they are abundant and easily collectible, have short life cycles, are sensitive to physical and chemical changes in the environment, and change the composition of their assemblages and their distribution in regions impacted by pollution [1-5]. The widespread use of these organisms promoted the establishment of guidelines for environmental monitoring of marine ecosystems and a protocol with standardized methods for soft-bottom benthic foraminiferal monitoring studies [6].

Benthic foraminifers do not live only at the sediment-water interface but can be found several centimeters deep in marine sediments. These microhabitats have a combination of physical, chemical, and biological characteristics. The species that inhabit superficial layers may differ from those inhabiting deeper layers forming assemblages with different faunal compositions [7]. However, microhabitats may change seasonally, and the species or genera can be found in different sediment layers according to favorable conditions or due to their development [8]. 
Foraminifera can be classified according to the depth they inhabit in marine sediments. Epifaunal, which live on the surface, shallow infaunal live in the range of $0-2 \mathrm{~cm}$, intermediate infaunal live in the range of 1-4 cm, and deep infaunal live below $4 \mathrm{~cm}$ [9]. Although this classification is functional, the depth mentioned for these categories can be variable over time, influenced by seasonal events. Therefore, we should not consider the exact depth in the sediment but the relative position of one species among the others [7].

Several deep-sea studies have addressed the vertical distribution of foraminifera. Usually, up to 10 centimeters depth is analyzed in the sediments, and in general, the densities are higher at superficial layers, decreasing with increasing depth [10-18]. It is still unclear whether only the surface layer of the sediment is sufficient to characterize a region based on foraminifera. Further studies are necessary to evaluate subsurface habitats occupied by foraminifera in different world regions [18]. It is also unknown whether the results of bathymetric zoning of deep regions change by including the lower layers.

Licari and Mackensen [19] questioned whether neglecting foraminifers from subsurface layers would harm environmental characterization based on their assemblages, bringing inaccuracy to paleoenvironmental interpretations. These authors studied the similarities and differences between surface $(0-1 \mathrm{~cm})$ and surface-plus subsurface assemblages $(0-5 \mathrm{~cm})$ in the southeastern Atlantic. They found that there were no significant differences in the distribution and composition of the assemblages. However, they emphasized that the result may be different in other oceanic regions due to environmental peculiarities.

The main objective of this study is to investigate the living benthic foraminifera from the surficial sediment layer $(0-2 \mathrm{~cm})$ applied to the environmental characterization of the continental slope at the Brazilian Equatorial Margin. Moreover, to verify whether the incorporation of foraminifers from the subsurface sediment layer $(2-5 \mathrm{~cm})$ of the slope changes the observed pattern, influencing regional understanding.

\section{Study Area}

The Potiguar Basin is located at the eastern end of the Brazilian Equatorial Margin (Figure 1).
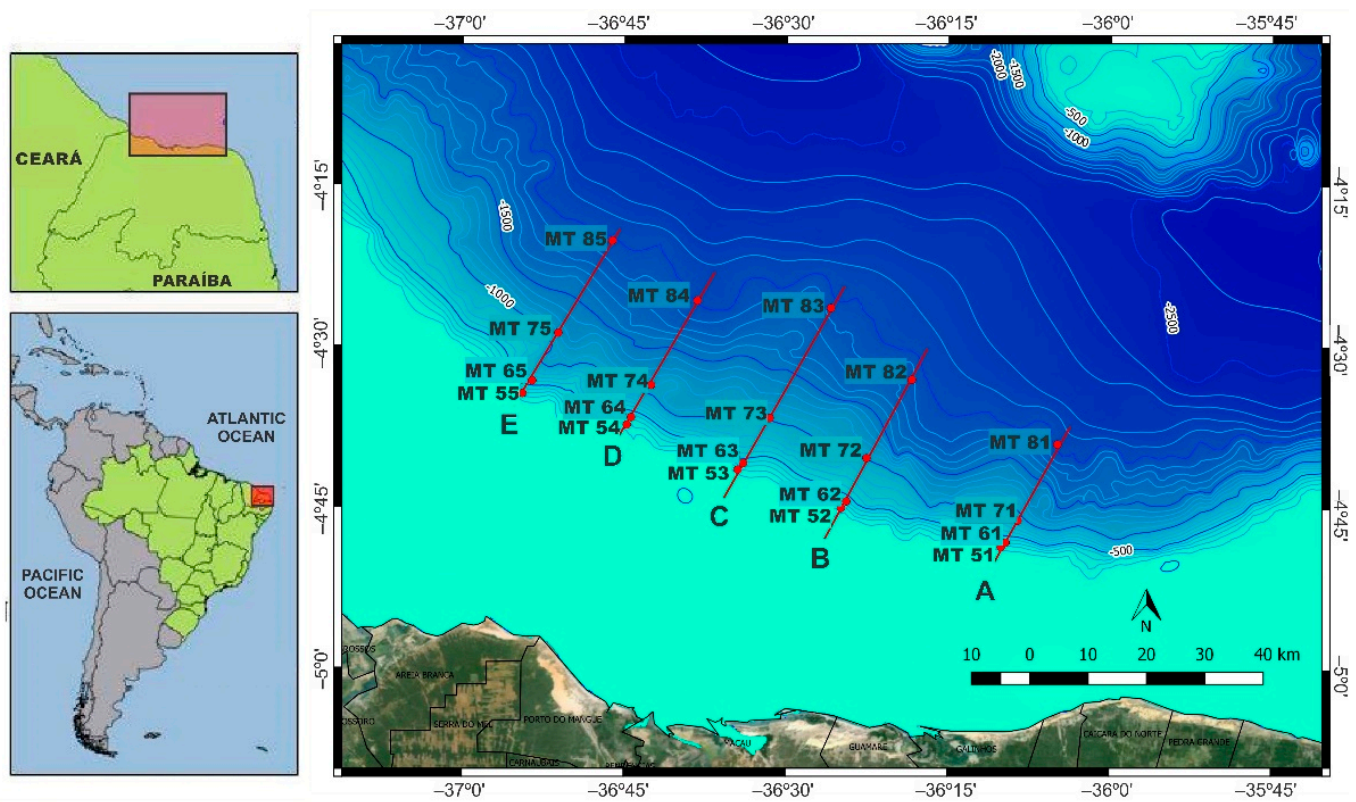

(a)

(b)

Figure 1. Study area. (a) South America-Brazil in green; rectangle delimiting the northern coast of Rio Grande do Norte. (b) Location of sampling stations at the continental slope $(\bullet)$; transects signed with the red lines.

The continental shelf is narrow and very different from the south of Brazil and southeast continental shelves. At the Rio Grande do Norte (NW Brazil), there is a strong declivity 
beginning at $\sim 70 \mathrm{~m}$. The continental slope starts at depths that usually belong to the middle/outer continental shelf in other Brazilian or other world regions. According to Almeida et al. [20], the upper slope occupies the area between the shelf break, at $70 \mathrm{~m}$, up to $300 \mathrm{~m}$ depth with a gradient of $15^{\circ}$, and the middle slope occupies between $300 \mathrm{~m}$ and $1300 \mathrm{~m}$ depth with a gradient of $6^{\circ}$. The abyssal plain begins at about $2000 \mathrm{~m}$ depth [21].

The vertical structure of the water column in the region is characteristic of the South Atlantic and composed of the following water masses: Tropical Water (TW), South Atlantic Central Water (SACW), Antarctic Intermediate Water (AIW), and North Atlantic Deep Water (NADW). TW has a higher temperature and salinity characteristics $\left(>20\right.$ and $>36^{\circ} \mathrm{C}$, respectively); SACW has temperatures between 6 and $20^{\circ} \mathrm{C}$, salinity ranging from 34.6-36, and a high concentration of nutrients; AIW has temperatures between 3 and $6{ }^{\circ} \mathrm{C}$, salinity between 34.2 to 34.6 , with high phosphate values; NADW has temperatures ranging between 3 and $4{ }^{\circ} \mathrm{C}$, and salinity between 34.6 and $35[22,23]$.

Systems of oceanic gyres and currents typify the ocean circulation in the South Atlantic; a subtropical anticyclonic gyre occupies the east-west extension of the ocean basin [22]. The South Equatorial Current (SEC) limits the Equatorial Gyre with the Subtropical Gyre of the South Atlantic [24]. The Cabo de São Roque region is divided into two Contour Currents: Brazilian Northern Subcurrent (BNS) in the north and Brazil Current (BC) in the south. These currents flow on the western continental margins of the ocean basins and are characterized by geophysical jets that present intense, narrow, and well-defined flows [25]. North of $5^{\circ} \mathrm{S}$, the BNS is influenced in its superficial portion by the contribution of the SEC with its central (CSEC) and equatorial (ESEC) branches and configures the intense flow of the North Brazil Current (NBC) that crosses the Equator in a northwest direction, closing the Equatorial Gyre at its western edge [24,26].

According to Testa and Bosence [27], the continental shelf of Rio Grande do Norte is a windward shelf without bays, estuaries, or rivers with significant inflow. Exposed to the full force of the western flow of the SEC faces strong winds and a large tidal range, resulting in a high-energy shelf facing the open ocean. The coast of Rio Grande do Norte is very unstable around $5^{\circ} \mathrm{S}$ due to the abrupt change in the shelf orientation associated with the intensity of the BNS. Associated with the northward flowing North Brazil Undercurrent (NBUC), a quasi-stationary subsurface anticyclone, the Potiguar Eddy, extends vertically from 100 to $400 \mathrm{~m}$ in Potiguar Basin, with maximum velocities of $0.6 \mathrm{~m} \mathrm{~s}^{-1}$ at the study area [28].

\section{Materials and Methods}

\subsection{Sediment Sampling}

Samples were collected aboard the RV Seward Johnson in transects perpendicular to the coastline and parallel one to another, crossing the isobaths of $150 \mathrm{~m}, 400 \mathrm{~m}, 1000 \mathrm{~m}$, and $2000 \mathrm{~m}$ totaling 20 sampling stations (Table 1). The stations were defined using characteristics of the water masses present in the region. Sediment samples were recovered using a box-core $\left(2500 \mathrm{~cm}^{2}\right)$ and/or a modified Van Veen grab with the top opening $(231 \mathrm{~L})$. At each station, samples $(10 \mathrm{~cm} \times 10 \mathrm{~cm} \times 10 \mathrm{~cm})$ were taken from each sampler using a stainless-steel box. The presence or absence of an anoxic layer was recorded, as well as signs of bioturbation. The cores were sliced into the surface $(0-2 \mathrm{~cm})$ and subsurface $(2-5 \mathrm{~cm})$ sediment layers, totaling 40 samples (Figure 2). Each sample was fixed with a $4 \%$ formaldehyde solution buffered with sodium tetraborate and stained with Rose Bengal to differentiate between living and dead foraminifers [29]. The surface layer was used for sedimentological analysis. 
Table 1. Data of sampling stations at the slope of the Potiguar Basin.

\begin{tabular}{ccccc}
\hline Sample & Lat & Long & Depth (m) & Water Mass \\
\hline MT51 & $04^{\circ} 29^{\prime} 10^{\prime \prime}$ & $36^{\circ} 06^{\prime} 02^{\prime \prime}$ & 167 & TW \\
MT52 & $04^{\circ} 27^{\prime} 01^{\prime \prime}$ & $36^{\circ} 14^{\prime} 56^{\prime \prime}$ & 203 & TW \\
MT53 & $04^{\circ} 24^{\prime} 54^{\prime \prime}$ & $36^{\circ} 20^{\prime} 41^{\prime \prime}$ & 133 & TW \\
MT54 & $04^{\circ} 22^{\prime} 23^{\prime \prime}$ & $36^{\circ} 26^{\prime} 51^{\prime \prime}$ & 128 & TW \\
MT55 & $04^{\circ} 20^{\prime} 39^{\prime \prime}$ & $36^{\circ} 32^{\prime} 40^{\prime \prime}$ & 145 & TW \\
MT61 & $04^{\circ} 28^{\prime} 55^{\prime \prime}$ & $36^{\circ} 05^{\prime} 47^{\prime \prime}$ & 400 & SACW \\
MT62 & $04^{\circ} 26^{\prime} 39^{\prime \prime}$ & $36^{\circ} 14^{\prime} 38^{\prime \prime}$ & 422 & SACW \\
MT63 & $04^{\circ} 24^{\prime} 32^{\prime \prime}$ & $36^{\circ} 20^{\prime} 23^{\prime \prime}$ & 394 & SACW \\
MT64 & $04^{\circ} 21^{\prime} 59^{\prime \prime}$ & $36^{\circ} 26^{\prime} 38^{\prime \prime}$ & 409 & SACW \\
MT65 & $04^{\circ} 19^{\prime} 57^{\prime \prime}$ & $36^{\circ} 32^{\prime} 07^{\prime \prime}$ & 408 & SACW \\
MT71 & $04^{\circ} 27^{\prime} 41^{\prime \prime}$ & $36^{\circ} 05^{\prime} 06^{\prime \prime}$ & 998 & AIW \\
MT72 & $04^{\circ} 24^{\prime} 12^{\prime \prime}$ & $36^{\circ} 13^{\prime} 31^{\prime \prime}$ & 1011 & AIW \\
MT73 & $04^{\circ} 22^{\prime} 01^{\prime \prime}$ & $36^{\circ} 18^{\prime} 55^{\prime \prime}$ & 1100 & AIW \\
MT74 & $04^{\circ} 20^{\prime} 11^{\prime \prime}$ & $36^{\circ} 25^{\prime} 31^{\prime \prime}$ & 983 & AIW \\
MT75 & $04^{\circ} 17^{\prime} 17^{\prime \prime}$ & $36^{\circ} 30^{\prime} 41^{\prime \prime}$ & 970 & AIW \\
MT81 & $04^{\circ} 23^{\prime} 26^{\prime \prime}$ & $36^{\circ} 02^{\prime} 55^{\prime \prime}$ & 2010 & NADW \\
MT82 & $04^{\circ} 19^{\prime} 51^{\prime \prime}$ & $36^{\circ} 11^{\prime} 01^{\prime \prime}$ & 1992 & NADW \\
MT83 & $04^{\circ} 15^{\prime} 52^{\prime \prime}$ & $36^{\circ} 15^{\prime} 31^{\prime \prime}$ & 1957 & NADW \\
MT84 & $04^{\circ} 15^{\prime} 28^{\prime \prime}$ & $36^{\circ} 22^{\prime} 57^{\prime \prime}$ & 1983 & NADW \\
MT85 & $04^{\circ} 12^{\prime} 08^{\prime \prime}$ & $36^{\circ} 27^{\prime} 41^{\prime \prime}$ & 2000 & NADW \\
\hline
\end{tabular}

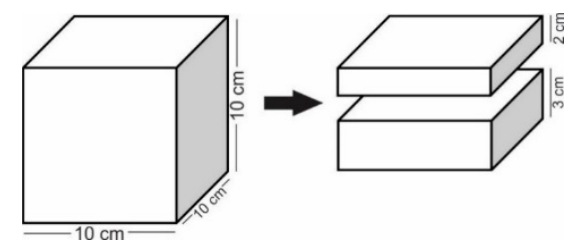

Figure 2. Schematic diagram of sampling sectioning (surface $0-2 \mathrm{~cm}$ and subsurface $2-5 \mathrm{~cm}$ ) layers.

\subsection{Granulometric Analysis}

The granulometric analysis was performed at the Laboratório de Geografia Física (LabGeoFis/UFRN). The sediment grain size was determined by dry sieving following Folk [30], in an electromagnetic sieve shaker (Produtest brand), with different mesh openings $(4 \mathrm{~mm}, 2 \mathrm{~mm}, 1 \mathrm{~mm}, 0.500 \mathrm{~mm}, 0.250 \mathrm{~mm}, 0.125 \mathrm{~mm}, 0.062 \mathrm{~mm}$ ). The fine fraction was quantified by pipetting.

\subsection{Foraminifera-Samples Processing}

All samples had their wet volume standardized to $100 \mathrm{~cm}^{3}$ and were washed under running water with a $63 \mu \mathrm{m}$ mesh sieve and oven-dried below $60^{\circ} \mathrm{C}$. The sediments were hand sieved $(63,125,250,500,850$, and $1000 \mu \mathrm{m}$ mesh) to improve the observation of different grain sizes. The $\geq 250 \mu \mathrm{m}$ fraction was entirely observed and counted, while the $<250 \mu \mathrm{m}$ fraction was quartered. The $\frac{1}{4}$ examined was corrected to $100 \mathrm{~cm}^{3}$. Each fraction was examined under a Zeiss SteREO Discovery.V8 microscope, 8:1 zoom range, 150× maximum magnification. All living foraminifera were collected and stored in micropaleontological slides. Tubular agglutinated species were not analyzed in this study. A difficulty encountered and raised by other authors (e.g., Fontanier et al. [16]) was the observation of the protoplasm in species with non-transparent tests such as some agglutinated and miliolid taxa. Using transmitted light, water, alcohol, and glycerin, we tried to see the protoplasm in these taxa. Nevertheless, the best way to overcome this problem was to break the tests after identification to confirm the status of living or dead.

Foraminiferal species were identified with the help of several publications (e.g., Ellis and Messina [31], Loeblich and Tappan [32,33], Hottinger et al. [34], Kaminski [35], Hayward et al. [36], Debenay [37], Kaminski and Cetean [38]; among others) and by comparison with material from museum collections, e.g., Museo Argentino de Ciencias Natu- 
rales "Bernardino Rivadavia"-Buenos Aires (Argentina), Smithsonian National Museum of Natural History-Washington D.C. (U.S.A.) and Natural History Museum-London (U.K.). Some of the specimens were imaged using a Scanning Electron Microscope and illustrated in the plates.

\subsection{Statistical Treatment}

Analyses were performed for three distinct data sets: surface layer $(0-2 \mathrm{~cm})$, subsurface layer $(2-5 \mathrm{~cm})$, and integrated layers $(0-5 \mathrm{~cm})$. These terms, as used hereafter, refer to the data sets of this study.

Diversity was assessed by species richness (S), Shannon's index $\left(\mathrm{H}^{\prime}\right)$, Pielou's evenness $\left(\mathrm{J}^{\prime}\right)$, and Dominance (D). $\mathrm{H}^{\prime}, \mathrm{J}^{\prime}$, and $\mathrm{D}$ were calculated only for densities higher than 50 ind./100 $\mathrm{cm}^{3}$. The bootstrap [39], a non-parametric resampling method that allows estimating wealth, was also used; an original data set is repeatedly sampled, creating various combinations of observations; these observations are used to define the standard error [40]. Unidentified specimens were excluded from these analyses.

Although the sampling effort was similar in the two layers $(0-2$ and $2-5 \mathrm{~cm})$, we estimated the species richness using rarefaction and extrapolation based on sample size [41] with the software R [42] and the iNEXT package [43]. This technique allows an inferential comparison of the diversity between groups with different sample sizes by constructing sampling curves for species richness. These curves are interpolated for smaller sample sizes or extrapolated to larger sample sizes [41,43]. These estimates should not be interpreted as representing the total richness or diversity of species at each depth interval, but rather as comparable estimates at the different depths $(0-2$ and 2-5 cm), as well as the comparison of these depths with the total evaluated layer $(0-5 \mathrm{~cm})$. In graphical representations, the shaded areas represent the confidence intervals calculated from the $95 \%$ bootstrap method.

Non-metric multidimensional scaling (NMDS) examines differences between areas and depths in species composition using Jaccard dissimilarities [44]. We performed the NMDS using the "metaMDS" function of the "vegan" package [45]. We used permutational multivariate analysis of variance (PERMANOVA, 9999 permutations) to determine differences in species composition by using the 'adonis2' routine available within the "vegan" package [45] and testing for significant clustering of depths across the post hoc test using "adonis.pair" routine available in the "EcolUtils" package [46].

Clustering analyses ( $Q$ mode) were applied using the hierarchical agglomerative clustering method (unweighted pair-group average-UPGMA) and the Bray-Curtis index to define foraminiferal assemblages [47]. For the curves, NMDS, PERMANOVA, and clustering analyses, only species with a relative frequency higher than or equal to $2 \%$ and occurrence in at least three samples were used. The Indicator Species Analysis [48] was applied to identify the significant species $(p<0.05)$ of each group of the superficial layer and their contribution within the group (Ind Val).

To correlate the abundance of species and environmental variables, a Canonical Correlation Analysis was performed, whose objective is to represent in its ordination axes the linear combinations between the data matrices [49]. To identify the correlations between foraminifera and environmental variables in the superficial layer, we used the biological matrix of indicator species and chlorophyll-a, pheophytin-a, dissolved oxygen, $\mathrm{pH}$, temperature, organic matter, anoxic layer, and percentage of sand and clay.

The list of species with the original names is given in Supplementary Materials Table S1. Selected species are illustrated in Plates I-IV (Appendix A).

\section{Results}

\subsection{Abiotic Data}

Sediments from $150 \mathrm{~m}$ and $400 \mathrm{~m}$ contained larger grain size particles. The highest sand content was observed at MT54 and MT53 (94.21\% and 91.48\%, respectively). Stations from $1000 \mathrm{~m}$ and $2000 \mathrm{~m}$ were silt-dominated. The highest silt contents were registered 
in MT81 and MT84 (65.20\% and 64.10\%, respectively). Clay percentage was low, with maximum rates $(27.13 \%)$ at MT82 (Figure 3).

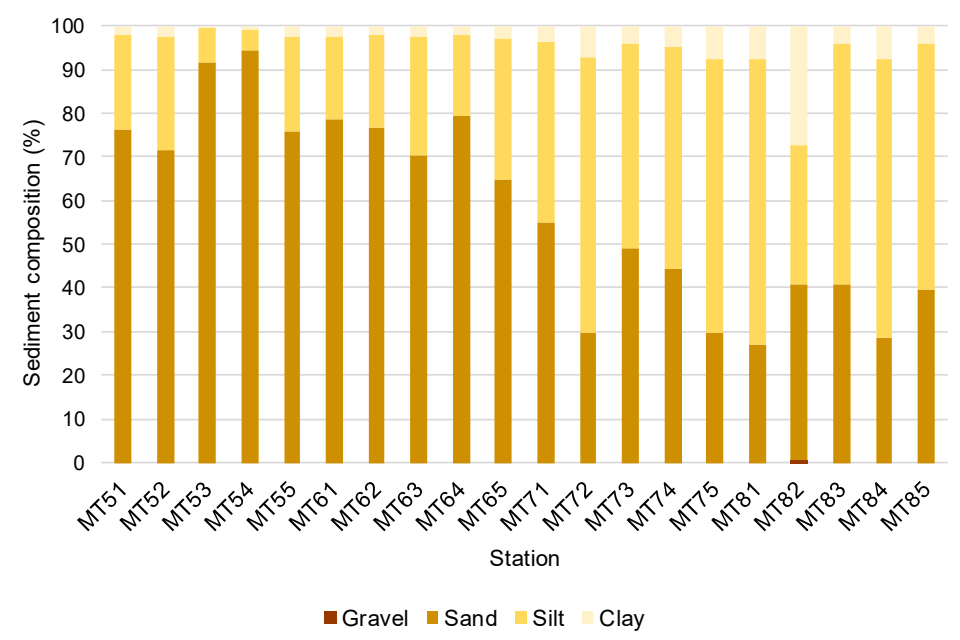

Figure 3. Sediments composition at the stations sampled at the Potiguar Basin Slope.

Anoxic layers were recorded at $400 \mathrm{~m}$, at 4 and $5 \mathrm{~cm}$ deep in samples MT63 and MT64.

The average percentage of organic matter was lower in the $400 \mathrm{~m}$ and $150 \mathrm{~m}$ isobaths and higher in 1000 and $2000 \mathrm{~m}$, varying from $6.93 \pm 2.22$ to $10.02 \pm 1.77$.

The parameters related to the water column are briefly described below. The mean temperature was higher in the $150 \mathrm{~m}$ isobath $(21.36 \pm 1.50)$ and decreased towards the deeper isobaths ( $400 \mathrm{~m} 8.38 \pm 1.05 ; 1000 \mathrm{~m} 4.16 \pm 0.05 ; 2000 \mathrm{~m} 3.40 \pm 0.07)$.

Dissolved oxygen was on average higher in the $2000 \mathrm{~m}$ isobath $(8.18 \pm 0.16)$. In the other isobaths, it ranged from $5.66 \pm 0.16$ in $400 \mathrm{~m}$ to $6.05 \pm 0.09$ in $150 \mathrm{~m}$.

On average, the $\mathrm{pH}$ was higher at $150 \mathrm{~m}(7.98 \pm 0.10)$ and reached the lowest value in $1000 \mathrm{~m}$ (7.69 \pm 0.06$)$, increasing slightly in $2000 \mathrm{~m}$ (7.81 \pm 0.05$)$.

The percentage of chlorophyll-a and pheophytin-a were lower in the $400 \mathrm{~m}$ and $150 \mathrm{~m}$ isobaths and higher in 1000 and $2000 \mathrm{~m}$. Chlorophyll-a ranged from $0.28 \pm 0.10$ in $400 \mathrm{~m}$ to $0.38 \pm 0.16$ in $1000 \mathrm{~m}$. Pheophytin-a ranged from $0.12 \pm 0.06$ in $400 \mathrm{~m}$ to $0.19 \pm 0.06$ in $1000 \mathrm{~m}$.

The main trends of abiotic data obtained during the project sampling are available in Supplementary Materials (Supplementary Figure S1).

\subsection{Foraminifera}

We recognized a total of 449 species and 193 genera in all samples. We recorded 396 species and 178 genera at the surface layer, and at the subsurface layer, 228 species and 127 genera. A total of 175 species were common to both layers, while 221 and 53 species were exclusive to the surface and subsurface layers, respectively.

We obtained $85.6 \%$ of the expected species from the surface layer, $84.26 \%$ of the expected species from the subsurface layer, with the same number of samples. Moreover, $86.36 \%$ of the expected species from the integrated layer at the study area (Table 2).

Table 2. The obtained and estimated richness (bootstrap) for the three studied layers of the Potiguar Basin Slope. $\mathrm{S}=$ richness observed; $\mathrm{S}(\mathrm{est})=$ Estimated richness.

\begin{tabular}{cccccc}
\hline Layer & S & S(est) 95\% CI Lower Bound & S(est) 95\% CI Upper Bound & Bootstrap & \% \\
\hline $0-2 \mathrm{~cm}$ & 396 & 376 & 416 & 463 \\
$2-5 \mathrm{~cm}$ & 228 & 212 & 244 & 271 \\
$0-5 \mathrm{~cm}$ & 449 & 428 & 470 & 520 & 84.60 \\
\hline
\end{tabular}

The richness analysis based on the occurrence of the species showed that 449 species were observed across the analyzed depth $(0-5 \mathrm{~cm})$, while at a depth of $0-2 \mathrm{~cm}, 396$ species 
were recovered, showing the ratio of the sampling effort concerning the total depth $(0-5 \mathrm{~cm})$ equivalent to 0.88 (interquartile range $=0.87-0.88$ ); and in $2-5 \mathrm{~cm}, 228$ species were found, with a sample effort ratio equivalent to 0.52 (interquartile range $=0.50-0.53$ ) (Figure 4 ).
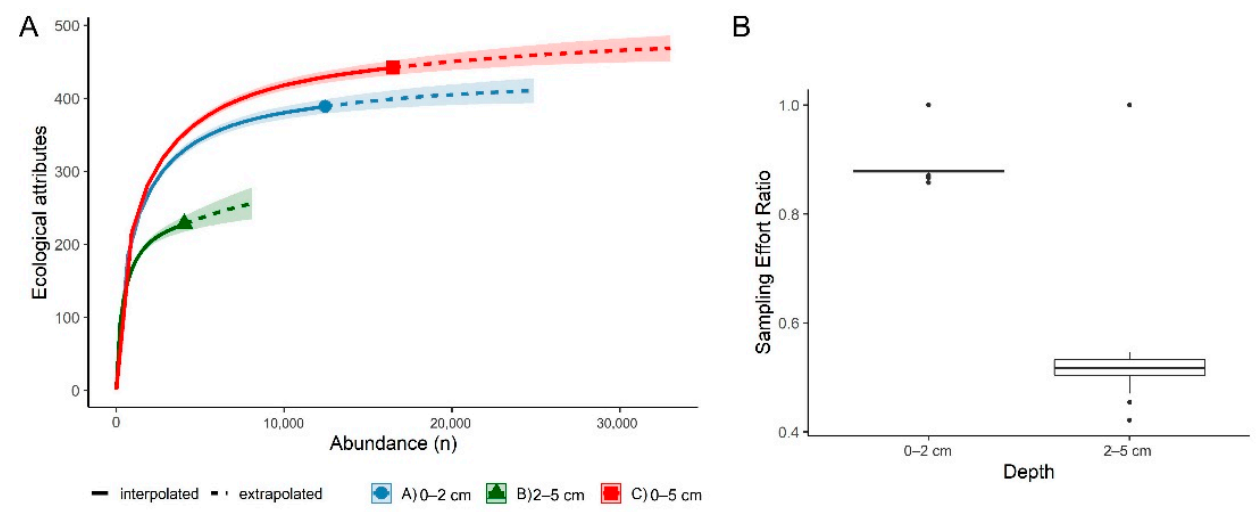

Figure 4. Richness analysis (A) Sampling curves for species richness comparing estimates at the different depths (0-2 and 2-5 cm) and comparing them with the total evaluated layer $(0-5 \mathrm{~cm})$. The shaded areas represent the confidence intervals. (B) Sampling effort ratio at integrated and subsurface layer.

\subsubsection{Density}

We recorded a total of 18,902 specimens in the study area, and the mean density was consistently higher on the surface than the subsurface layer. Foraminiferal densities varied between 118 (MT85) and 1835 (MT55) individuals $/ 100 \mathrm{~cm}^{3}$ in the surface (total $=14,222$ specimens) compared to 42 (MT81) and 1160 (MT53) individuals $/ 100 \mathrm{~cm}^{3}$ in the subsuperficial layer (total $=4680$ specimens). Only one station of the middle slope (1000 m) (MT74) presented a higher density at the subsurface layer (Figure 5a).

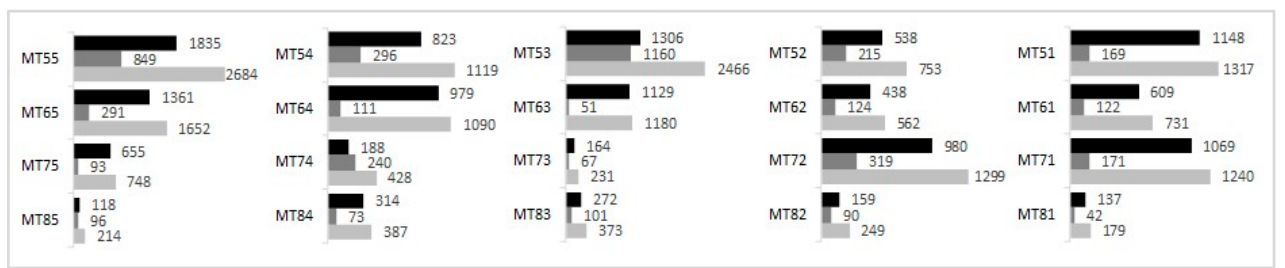

(a)

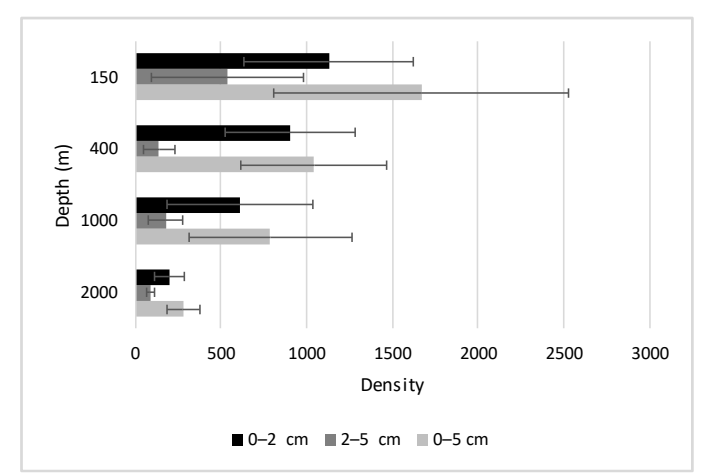

(b)

Figure 5. Density of foraminifera. (a) Per station at the layers. (b) Mean and standard deviation per isobath at the studied layers.

At the surface layer, the mean density was higher at $150 \mathrm{~m}(1130 \pm 493.21$ standard deviation), decreasing towards the deeper isobaths $(400 \mathrm{~m}=903.2 \pm 377.25 ; 1000 \mathrm{~m}=611.2 \pm 426.20$ and $2000 \mathrm{~m}=200 \pm 87.40$ ). At the subsurface layer, the mean density was higher at $150 \mathrm{~m}$ (537.8 \pm 442.34$)$ and $1000 \mathrm{~m}(178 \pm 104.07)$. The mean values were lower at $400 \mathrm{~m}$ and $2000 \mathrm{~m}$ with $139.8 \pm 89.64$ and $80.4 \pm 23.92$, respectively (Figure $5 b$ ). 


\subsubsection{Diversity}

Species richness was predominantly higher at the surface, except for station MT74 (S $=29$ surface; $S=41$ subsurface). The highest surficial layer's $S$ values occurred at $400 \mathrm{~m}$ $(\bar{x}=90 \pm 27.61)$, decreasing toward deeper isobaths. In the subsurface layer, the mean $S$ was higher at $150 \mathrm{~m}(\bar{x}=41 \pm 17.99)$, varying at $400 \mathrm{~m}$ and $1000 \mathrm{~m}$, and the lowest values occurred at $2000 \mathrm{~m}$ in both layers, surface $\bar{x}=31.2 \pm 8.41$ and subsurface $\bar{x}=18.25 \pm 3.59$ (Figure 6a).

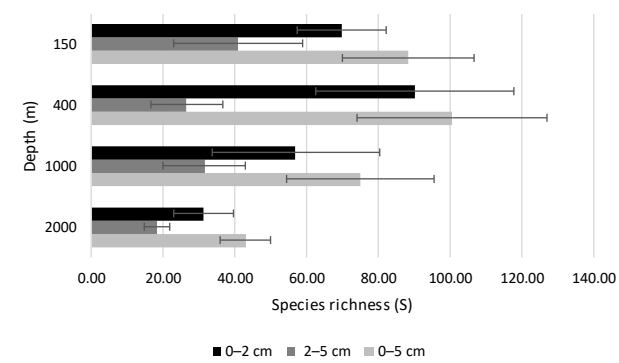

(a)

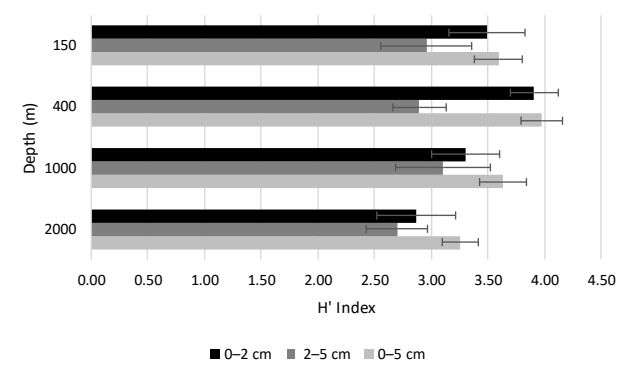

(b)

Figure 6. The mean and standard deviation of foraminifera species diversity along the studied isobaths at the surface, subsurface, and integrated layer. (a) Species richness; (b) Shannon's index.

The higher $\mathrm{H}^{\prime}$ diversity index values occurred at the surface layer; the highest was registered at $400 \mathrm{~m}\left(\mathrm{H}^{\prime}=4.18\right.$, MT65) while the lowest at $2000 \mathrm{~m}\left(\mathrm{H}^{\prime}=2.49\right.$, MT82) (Figure 6b). $\mathrm{H}^{\prime}$ diversity had few changes at the subsurface layer; the highest value occurred at $1000 \mathrm{~m}$ $\left(\mathrm{H}^{\prime}=3.49, \mathrm{MT72}\right)$, and the lowest at $2000 \mathrm{~m}\left(\mathrm{H}^{\prime}=2.31\right.$, MT84).

The subsurface layers showed higher equitability $\left(\mathrm{J}^{\prime}\right)$ mean values, increasing towards the deep sea, except at $150 \mathrm{~m}$, where both layers presented the same average $(\bar{x}=0.82 \pm 0.06$ in surface and $\bar{x}=0.82 \pm 0.1$ in subsurface). At the surface layer, the lower values were registered at $150 \mathrm{~m}$ (Figure 7a).

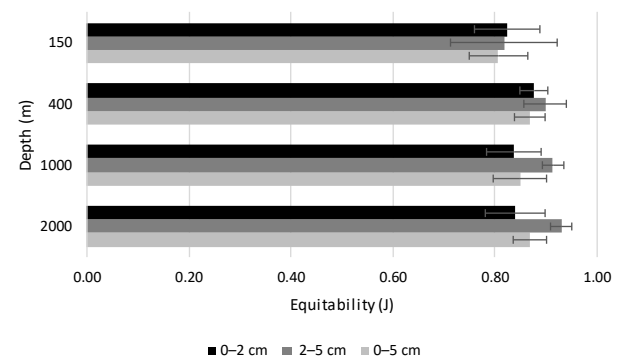

(a)

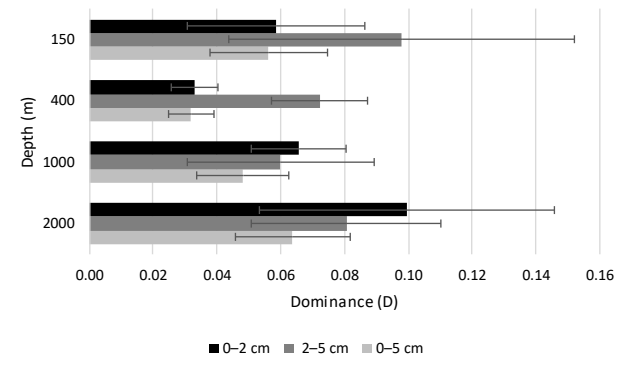

(b)

Figure 7. The mean and standard deviation of foraminifera equitability (a) and dominance (b) along the isobaths at the studied layers.

The dominance (D) varied among layers and isobaths (Figure 7b). It was higher at $150 \mathrm{~m}$ on the subsurface layer $(\bar{x}=0.10 \pm 0.05)$. At the surface layer, its higher values were registered at $2000 \mathrm{~m}(\bar{x}=0.1 \pm 0.04)$, and $1000 \mathrm{~m}(\bar{x}=0.07 \pm 0.01)$.

After integrating the layers, in general, the patterns observed in the surface are maintained for the community structure. These values are presented in Supplementary Materials Table S2.

\subsubsection{Composition of Assemblages: Major Taxa}

At the surface layer, the dominant species (Rel.Freq. $>4 \%$ ) at $150 \mathrm{~m}$ are Bigenerina textularioidea, Angulogerina occidentalis s.l., and Sigmavirgulina tortuosa; at $400 \mathrm{~m}$ are Trifarina bradyi and Siphonina bradyana; at $1000 \mathrm{~m}$ are Epistominella sp. 1, Reophax spiculifer, Bolivina pseudoplicata and Bolivina albatrossi; at $2000 \mathrm{~m}$ are Karrerulina sp. A, Bolivina pseudoplicata, Repmanina charoides, Reophax hispidulus and Lituotuba lituiformis (Figure 8). 


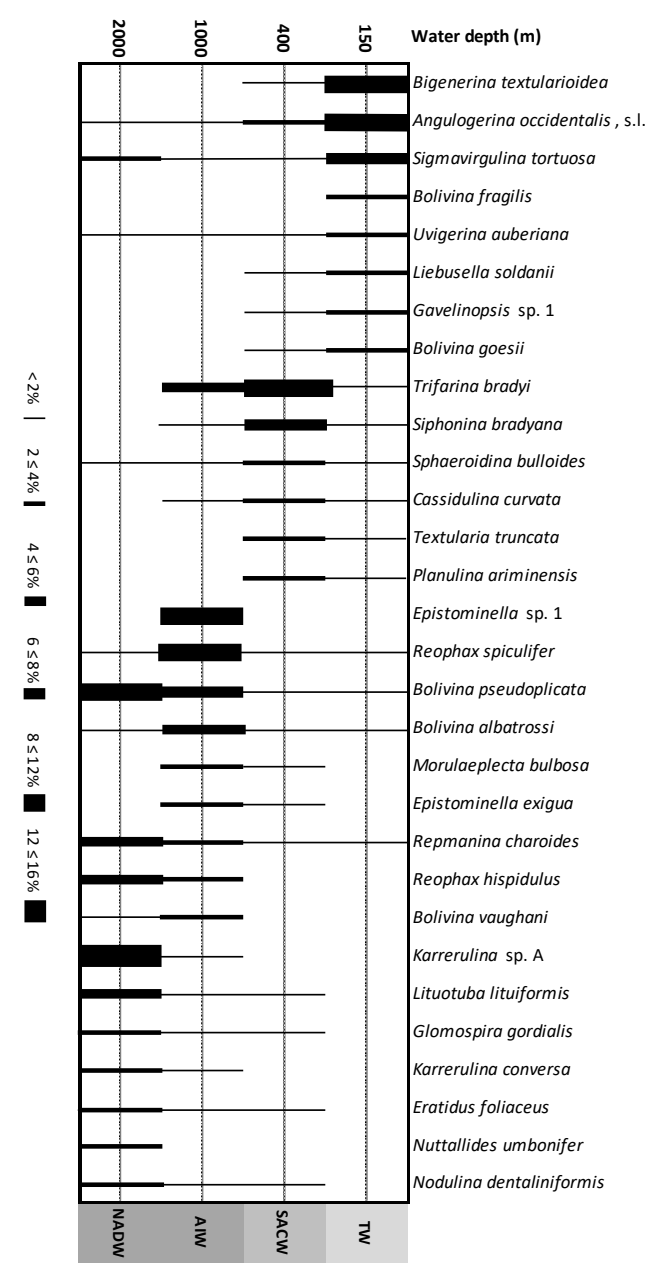

Figure 8. Species and their respective relative frequencies at the superficial layer.

At the subsurface layer, the dominant species (Rel.Freq. $>4 \%$ ) at $150 \mathrm{~m}$ are Bigenerina textularioidea, Liebusella soldanii, Angulogerina occidentalis s.l., and Sigmavirgulina tortuosa; at $400 \mathrm{~m}$ are Siphonina bradyana, Trifarina bradyi, Textularia truncata, Psammosphaera fusca s.1., Angulogerina occidentalis, s.l., and Lagenammina? sp. 2; at $1000 \mathrm{~m}$ are Repmanina charoides, Paratrochammina brasiliensis, and Nouria harrisii; at $2000 \mathrm{~m}$ are Gyroidina sp. 2, Paratrochammina brasiliensis, Nouria harrisii, Bolivina pseudoplicata, Pullenia aff. subcarinata, Bolivina vaughani, Nuttallides umbonifer and Trochamminidae indet. 6 (Figure 9).

When layers are integrated, the species with relative frequency $>4 \%$ at $150 \mathrm{~m}$ are Bigenerina textularioidea, Angulogerina occidentalis, s.l., and Sigmavirgulina tortuosa, but also Liebusella soldanii joins the group. Trifarina bradyi and Siphonina bradyana remain to represent the group at $400 \mathrm{~m}$. At $1000 \mathrm{~m}$, the species with relative frequency $>4 \%$ are Epistominella sp. 1, Reophax spiculifer and Bolivina pseudoplicata. At the $2000 \mathrm{~m}$ depth, species with higher $(>4 \%)$ relative frequency are Karrerulina sp. A, Bolivina pseudoplicata and Paratrochammina brasiliensis (Figure 10). All values are presented in Supplementary Materials Table S3. 


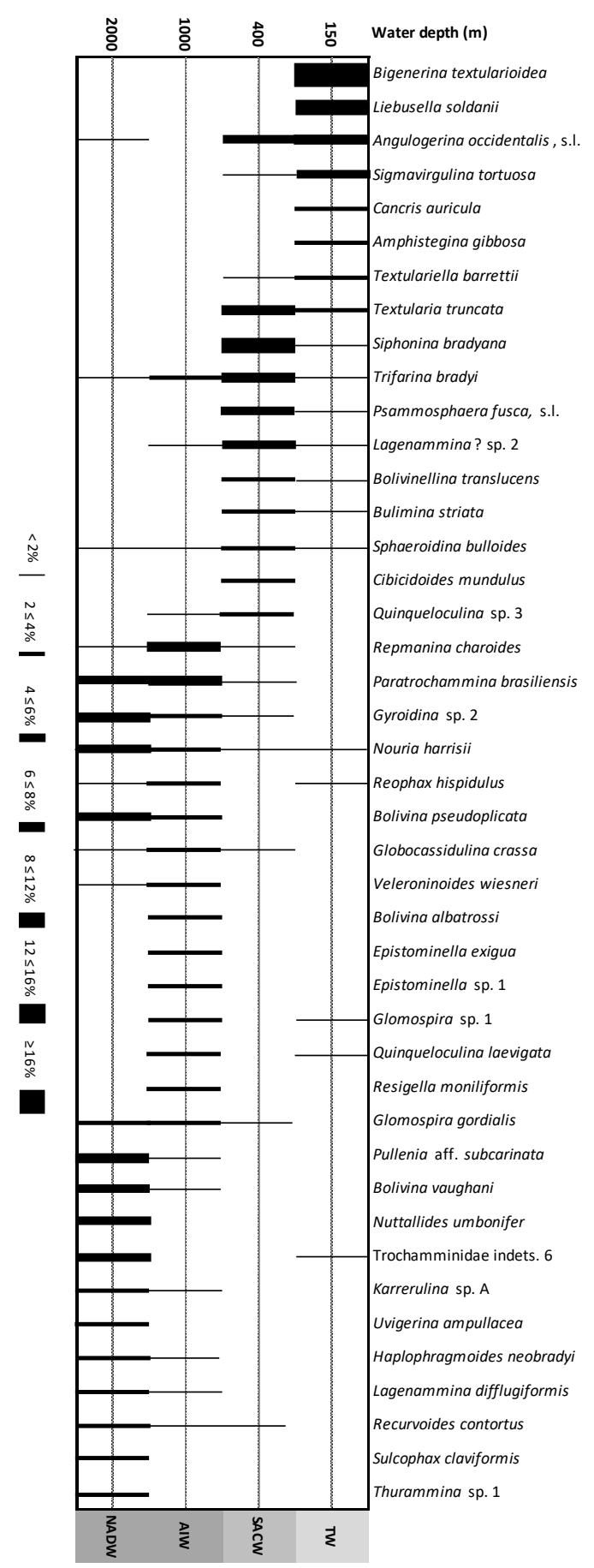

Figure 9. Species and their respective relative frequencies at the subsurface layer.

\subsubsection{Comparison of Assemblages}

The species composition significantly differed among depths $(\mathrm{F}=1.705 ; p=0.0063)$. The assemblage at $0-2 \mathrm{~cm}$ was statistically similar to that at $0-5 \mathrm{~cm}(\mathrm{~F}=0.334 ; p=0.999)$, while the assemblage at the depth of $2-5 \mathrm{~cm}$ was statistically different from the layers of $0-2 \mathrm{~cm}$ and $0-5 \mathrm{~cm}(\mathrm{~F}=2.605, p<0.0001 ; \mathrm{F}=2.658, p<0.0001$, respectively).

The NMDS revealed that $2-5 \mathrm{~cm}$ depth tree species composition did not represent the $0-5 \mathrm{~cm}$ depth assemblage as $0-2 \mathrm{~cm}$ represented it (Figure 11). 


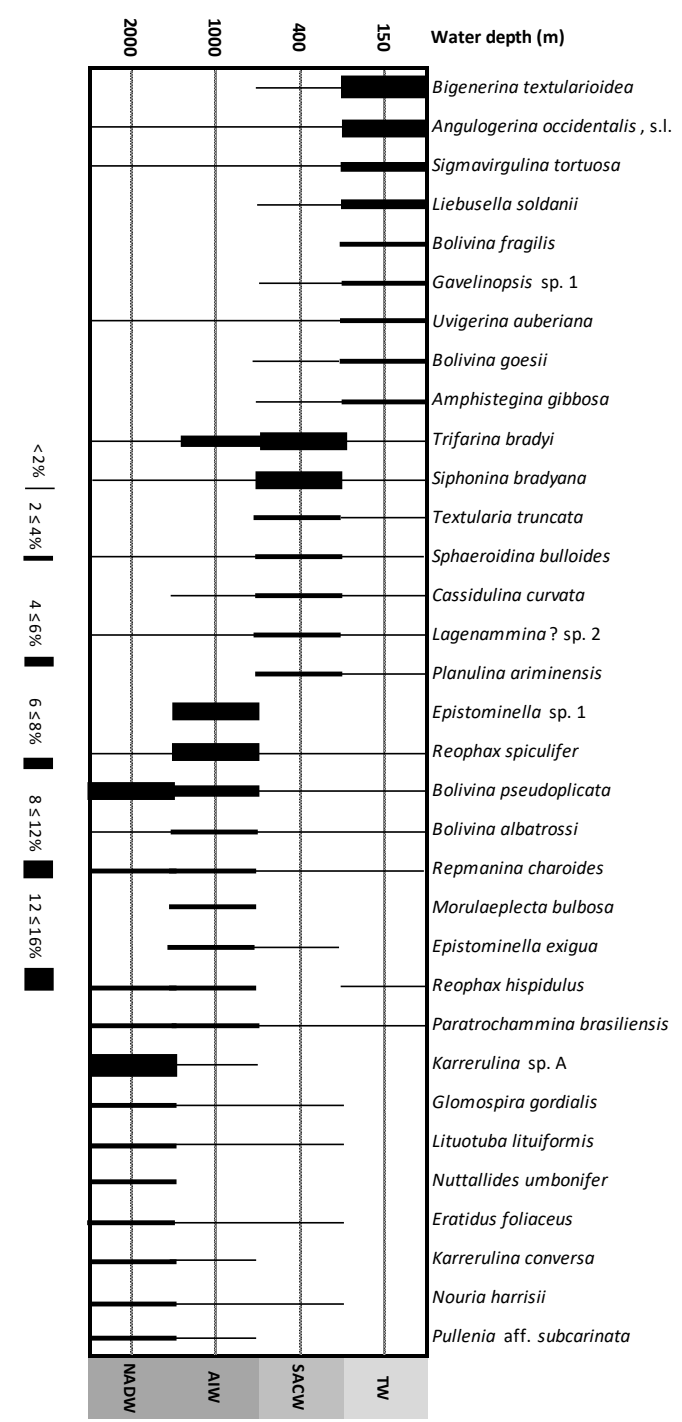

Figure 10. Species and their respective relative frequencies at the integrated layer.

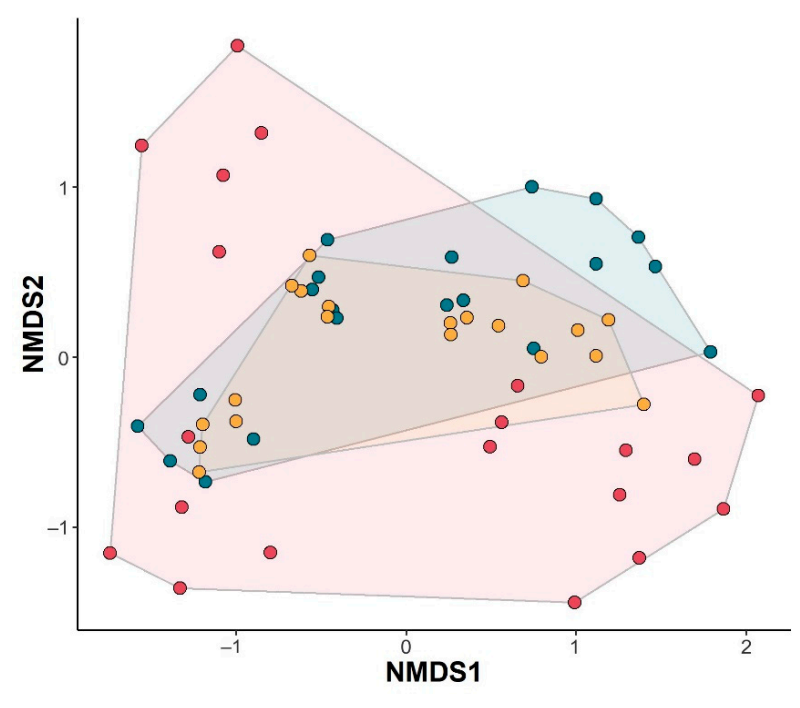

Depths $\quad 0-2 \mathrm{~cm} \quad 2-5 \mathrm{~cm} \quad 00-5 \mathrm{~cm}$

Figure 11. Non-metric multidimensional scaling (NMDS) of three study layers from the continental slope of Potiguar Basin based on the tree of foraminiferal species composition: blue-surface layer $(0-2 \mathrm{~cm})$; red-subsurface layer $(2-5 \mathrm{~cm})$; yellow-integrated layer $(0-5 \mathrm{~cm})$. 


\subsubsection{Cluster Analysis}

Three distinct dendrograms based on foraminiferal assemblages are illustrated in Figure 12.

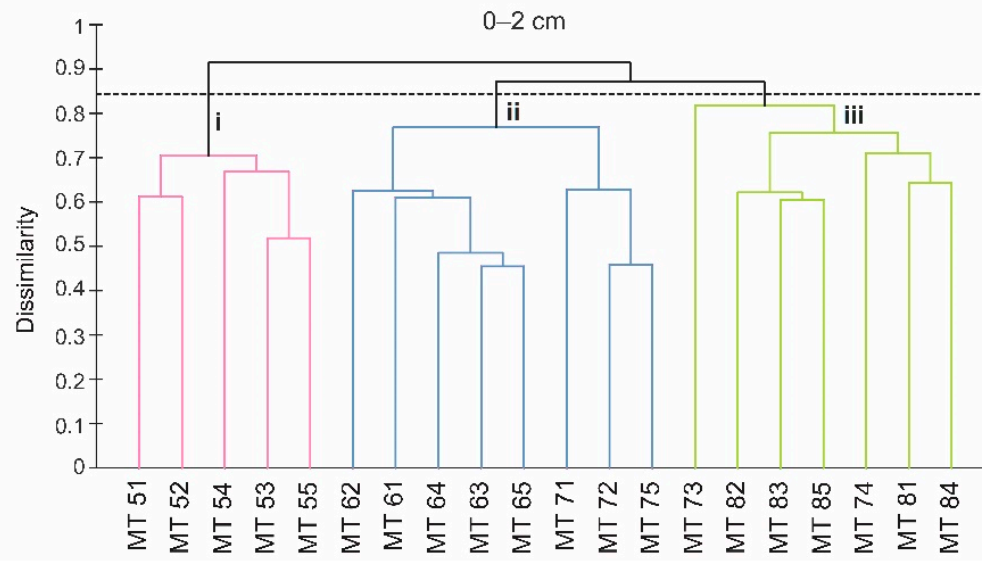

(a)

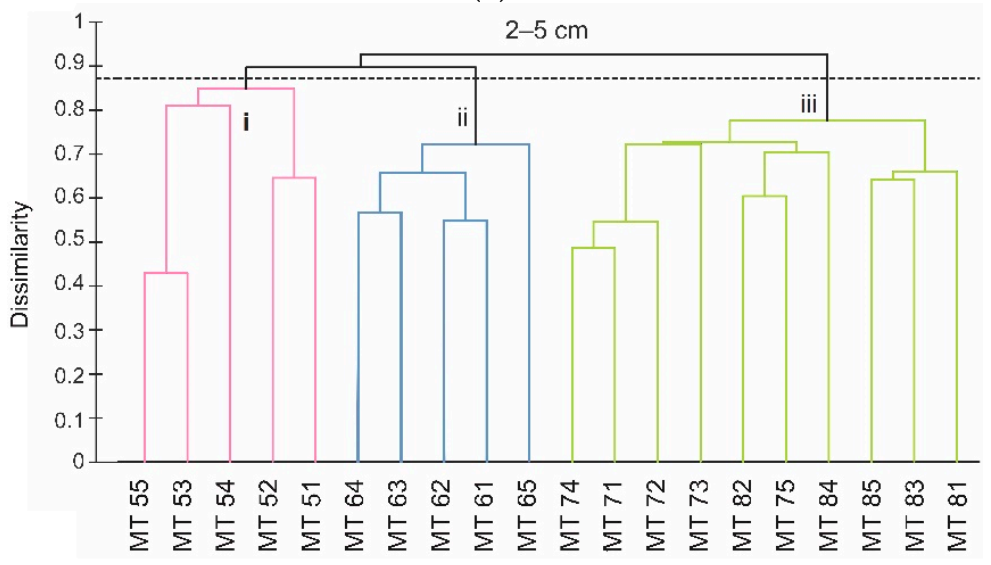

(b)

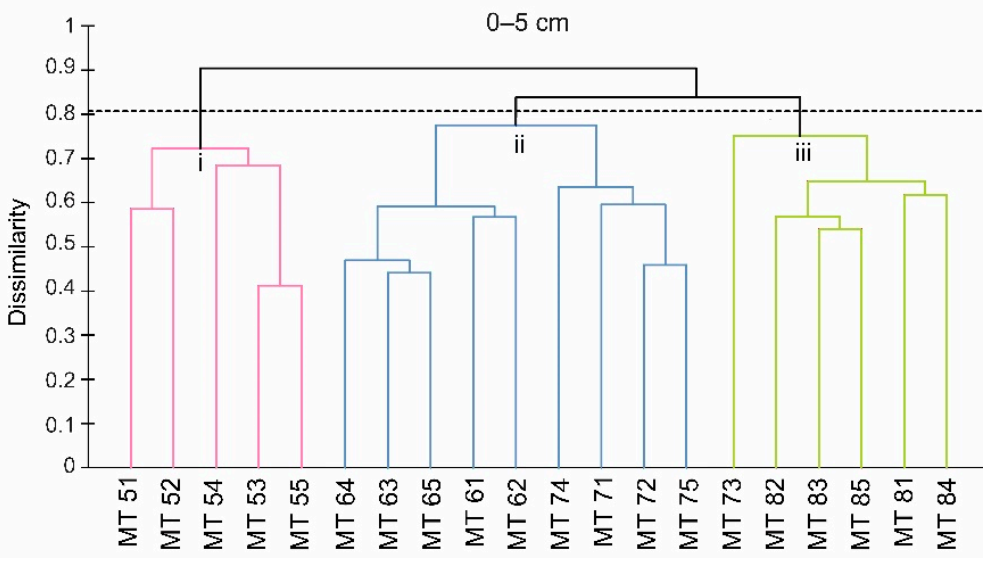

(c)

Figure 12. Dendrograms based on foraminiferal assemblages. (a) Surface layer. (b) Subsurface layer. (c) Integrated layer. Groups: (i) upper slope, (ii) middle slope, and (iii) lower slope.

Three main groups are identified at the dendrogram from the surface layer. Group I comprises all the samples from $150 \mathrm{~m}$ isobath, indicating the area of the upper slope. Group II joins all the samples from the $400 \mathrm{~m}$ isobath and three samples from $1000 \mathrm{~m}$ (MT71, MT72, and MT75), indicating the area of the middle slope. Group III joins all the samples from $2000 \mathrm{~m}$ isobath and two samples from $1000 \mathrm{~m}$ (MT73 and MT74), mostly indicating the lower slope (Figure 12a). 
Three main groups are identified at the dendrogram from the subsurface layer. Group I comprises all the samples from $150 \mathrm{~m}$ isobath, indicating the area of the upper slope. Group II joins all the samples from $400 \mathrm{~m}$, indicating the middle slope. Group III comprises all the samples from $1000 \mathrm{~m}$ and $2000 \mathrm{~m}$, indicating middle to lower slope areas (Figure 12b).

The cluster produced by integrated layers shows a similar pattern to the observed in the surface layer analysis, with minor differences, especially within the samples from 400 and $1000 \mathrm{~m}$. Three groups are observed. Group I comprises all the samples from $150 \mathrm{~m}$, indicating the upper slope. Group II joins all the samples from $400 \mathrm{~m}$ and most samples from $1000 \mathrm{~m}$, except for MT73, indicating the middle slope region. Sample MT73 belongs to Group III, with all samples from $2000 \mathrm{~m}$, indicating the lower slope region (Figure 12c).

The main indicator species $(p<0.05$; and IndVal $>0.6)$ of dendrogram from the surface layer are available in Supplementary Table S4 (Supplementary Materials).

\subsubsection{Canonical Correspondence Analysis}

The CCA showed that the species are correlated with the variables data $(p<0.0001)$ and explained $65.71 \%$ of the variance (Figure 13 ).

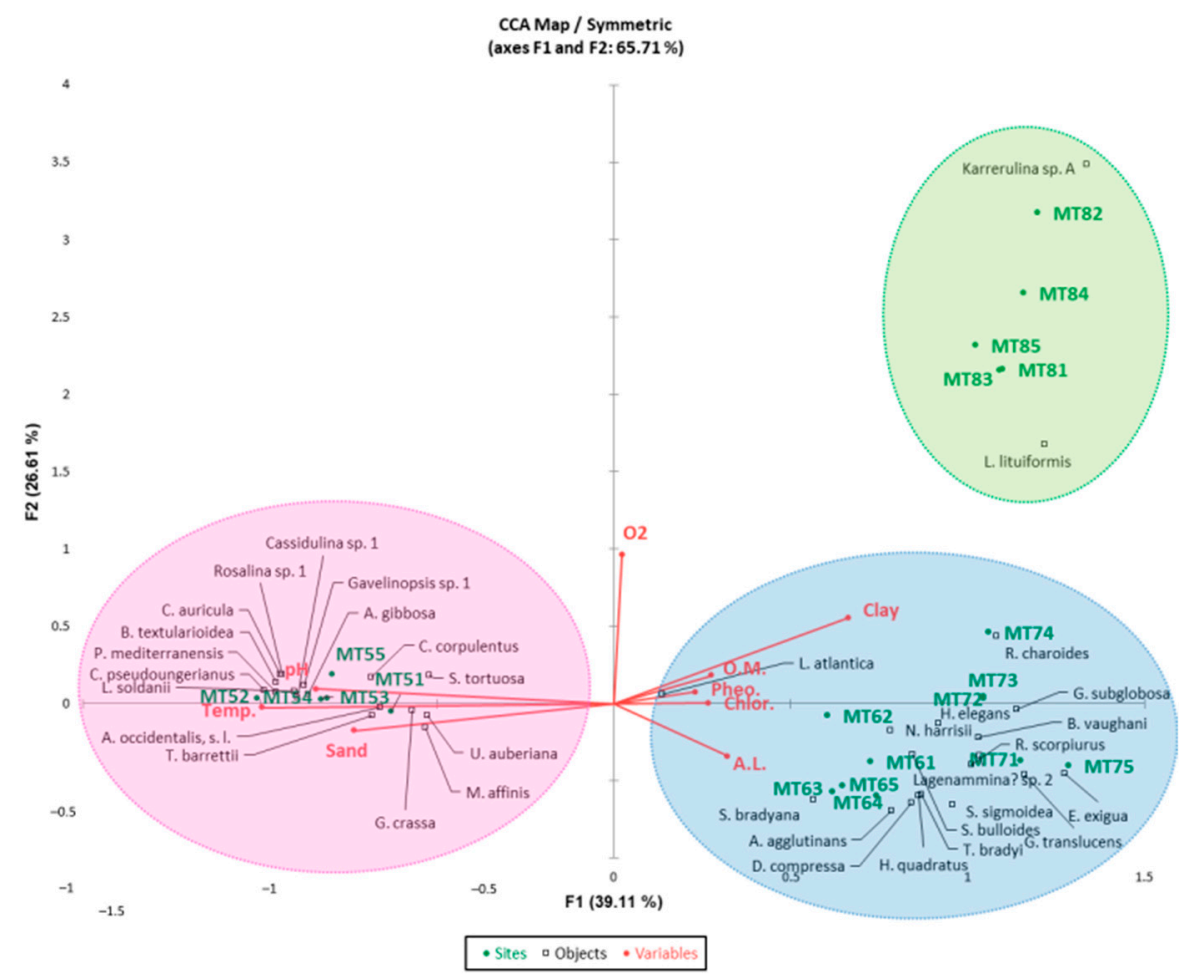

Figure 13. Ordering diagram with the result of CCA performed with indicator species of superficial layer and abiotic variables. Environmental descriptors in red. Temp.: Temperature; A.L.: Anoxic Layer; O.M.: Organic Matter; $\mathrm{O}_{2}$ : Dissolved Oxygen; Sand, Clay, Chlo: chlorophyll-a; Pheo: pheophytin-a, and pH. Ellipses: pink-upper slope, blue-middle slope; green-lower slope.

The three main regions are mentioned below and related to environmental parameters.

In the upper slope $(150 \mathrm{~m})$, the indicator species were: Rosalina sp. 1, Bigenerina textularioidea, Liebusella soldanii, Amphistegina gibossa, Cibicidoides corpulentus, Angulogerina occidentalis, s.l., Globocassidulina crassa and Textulariella barretii. Sands dominated the sediments, the $\mathrm{pH}$ and temperature were higher (on the diagram, highlighted in pink).

In the middle slope (400-1000 m), the indicator species were: Reophax scorpiurus, Trifarina bradyii, Gavelinopsis translucens, Sphaeroidina bulloides, Hoeglundina elegans, Discammina compressa and Haplophragmoides quadratus. At $400 \mathrm{~m}$ isobath sediments, we observed the lowest mean organic matter content, as lowest values of pheophytin-a, chlorophyll-a, dissolved oxygen, 
and the presence of an anoxic layer. At $1000 \mathrm{~m}$ isobath, the sediments were dominated by silt and clay fractions, and registered the highest mean organic matter content, as the values of pheophytin-a and chlorophyll-a (on the diagram, highlighted in blue)

In the lower slope ( $2000 \mathrm{~m})$, the indicator species were Karrerulina sp. A and Lituotuba lituiformis. The sediments were dominated by silt and clay fractions. This isobath had the lowest temperature and highest dissolved oxygen concentration. The organic matter, pheophytina, and chlorophyll-a values were similar to those recorded at $1000 \mathrm{~m}$ (on the diagram, highlighted in green).

\section{Discussion}

The Brazilian continental margin has many carbonate areas dominating the continental shelf with sandy and gravel sediments usually well-oxygenated, especially in the northeastern region [50]. Sampling and sectioning the first centimeter at sandy and gravel bottom may be complicated sometimes, and a one-centimeter sampling layer might not adequately represent the foraminiferal assemblages. For that reason, most studies performed at the Brazilian shelves have been done with the first two surficial centimeters, aiming to study the epifaunal and the shallow infaunal species.

Schönfeld et al. [6] strongly suggest that replicates should be used in biocenosis studies, especially in environmental monitoring studies, to cover the heterogeneous distribution of foraminiferal assemblages.

This study is part of the environmental characterization of the Potiguar Basin slope area that aims for future monitoring activities. Although the other replicas were not used in this study, the sampling design was carried out on a regular grid and allowed five replicates per isobath, providing a consistent spatial pattern of the foraminiferal assemblages along the bathymetric gradient. Later on, other data may be evaluated, making it possible to discuss microhabitat variation and the variance within the foraminiferal assemblages. The bootstrap analysis indicated that more than $86 \%$ of the expected species were recovered, showing the spatial distribution of foraminiferal assemblages along the bathymetric gradient, and increasing the information available for the region. We also emphasize that the characterization of the foraminiferal assemblage using only the first two centimeters of sediment was enough to represent $88 \%$ of the species composition, being important evidence to reduce the sampling efforts.

Studies investigating foraminiferal distribution in space and time have described that they are distributed by pulsating patches [51]. In this study, it was not possible to evaluate the temporal distribution. The spatial distribution of foraminiferal density varied widely between stations of the same depth and between the two layers studied, showing the expected patchy distribution. Higher average densities occurred in the stations of the upper slope $(150 \mathrm{~m})$, decreasing towards the lower slope $(2000 \mathrm{~m})$, similar to the trends observed in other continental slope regions $[13,52-56]$. The superficial layer had the highest densities; $75.24 \%$ of the specimens occurred in this layer, while $24.76 \%$ occurred in the subsurface layer. In general, the highest concentration occurs in the first centimeter, with a decrease in density as it goes down vertically [12-15].

The area with the highest diversity at the surface layer was the middle slope $(400 \mathrm{~m})$. This region is under the influence of the SACW, rich in nutrients, and it probably influenced the foraminiferal assemblages. At the subsurface layer, the areas with the highest diversity values $\left(\mathrm{S}\right.$ and $\left.\mathrm{H}^{\prime}\right)$ were the upper slope $(150 \mathrm{~m})$ and the middle slope $(1000 \mathrm{~m})$, respectively. The presence of sands and very poorly selected sediments at the $150 \mathrm{~m}$ isobath might have favored interstitial oxygenation at the subsurface layer, enhancing foraminiferal diversity and density.

Amphistegina gibbosa was recorded on the upper slope surface, and subsurface layers, and on the surface layer of the middle slope $(400 \mathrm{~m})$. The presence of living specimens of A. gibbosa at the slope is herein attributed to the transported material from the continental shelf, where this species is abundant. As commented before, the continental shelf is narrow at NE Brazil. It presents a strong declivity, beginning at $\sim 70 \mathrm{~m}$, favoring species from the 
continental shelf to be transported downwards to the slope by currents once the activity of the Potiguar Eddy also influences the hydrodynamics at a regional scale. The preservation of the protoplasm for a short period after death is not uncommon [57]. They can be stained by the Bengal Rose, artificially extending its distribution inadvertently to areas where they are not established.

The low values of density and diversity in the subsurface layer of the middle slope $(400 \mathrm{~m})$ are probably associated with an anoxic layer between $4 \mathrm{~cm}$ and $5 \mathrm{~cm}$ deep in the sedimentary column registered during sampling activities. Although Trifarina bradyi occurred in all isobaths with variable densities, it was the most abundant species in the middle slope $(400 \mathrm{~m})$ at the surficial layer and the second most abundant species in the subsurface $(8.55 \%$ and $7.68 \%$, respectively). T. bradyi is strongly associated with anoxia or dysoxia events and is usually known as a probably facultative species under those conditions $[58,59]$. The two stations with the great abundance of this species coincided with the presence of the anoxic layer.

The increase in diversity close to the middle slope is consistent with patterns recorded by Buzas and Gibson [60] and Gibson and Buzas [61] for the North Atlantic, and also by Hayward et al. [36] for the west coast of New Zealand. These authors observed an increase in diversity near the platform and a maximum in the upper bathyal region (between $200 \mathrm{~m}$ and $600 \mathrm{~m}$ ), followed by a slight decline towards the abyssal areas. Disaró et al. [62] found the greater diversity of foraminifers at Potiguar Basin on the carbonate areas of the middle and outer shelf and at the middle slope $(370 \mathrm{~m})$. At the Campos Basin, southeastern Brazilian continental margin, the higher relative richness of foraminifers at the first two centimeters of the slope occurred at $400 \mathrm{~m}$ to $1000 \mathrm{~m}$. In contrast, the lower values occurred from $1300 \mathrm{~m}$ to $3000 \mathrm{~m}$ (middle to lower slope) [63].

The subsurface layer had the most constant density, diversity, and evenness in the middle and lower slope. The dominance was usually higher in this layer. The most abundant species responsible for this dominance were Bigenerina textularioidea (21.55\%) and Liebusella soldanii (8.68\%) in the upper slope, and Siphonina bradyana $(10.56 \%)$ and Trifarina bradyi $(7.68 \%)$ in the middle slope $(400 \mathrm{~m})$.

Regarding the specific foraminiferal composition, we observed that in the upper slope, about $50 \%$ of the most abundant species were common to the surface and subsurface layers; at $400 \mathrm{~m}$, this ratio was variable, and at $1000 \mathrm{~m}$ and $2000 \mathrm{~m}$, there were about $35 \%$ of the most abundant species common to both layers. Calcareous hyaline and agglutinated foraminifera with a robust test (e.g., Bigenerina textularioidea and Liebusella soldanii) are among the dominant species of the upper slope. These species can live in higher energy environments, represented by the domain of gravel and sand fractions. The number of calcareous species decreased towards deeper stations, and fragile agglutinated species increased, including several species of Reophax, Repmanina charoides, and Eratidus foliaceous increase their densities where the silt and clay fractions dominate.

Regardless of which layer is used, the results show that the distribution of foraminiferal assemblages is strongly associated with the bathymetric gradient and bottom topography. The sedimentary properties also influenced the establishment of the assemblages. Sand fractions predominated in the upper slope, and silt and clay dominate deep regions (middle $1000 \mathrm{~m}$ and lower slope). The middle slope $(400 \mathrm{~m})$ is dominated by the sand fraction.

Data also indicate that the water masses influence the oxygen content, $\mathrm{pH}$, and nutrients availability. The currents and Potiguar Eddy affect the upper and middle slope sediment deposition and other physicochemical properties [28,64]. The species Bigenerina textularioidea, Angulogerina occidentalis, s.l., Sigmavirgulina tortuosa, Liebusella soldanii, Bolivina fragilis, Gavelinopsis sp. 1, and Uvigerina auberiana were abundant throughout the upper slope. According to Murray [59], Trifarina angulosa, Adercotryma glomeratum, Aschemonella ramuliformis, Cribrostomoides subglobosus, Cribrostomoides weddellensis and Hoeglundina elegans are characteristic species of associations exposed to intense bottom currents.

The North Subcurrent of Brazil, with the influence of the South Equatorial Current, configure the North Brazilian Current, which exerts an intense flow in this area [25]. According 
to Mackensen et al. [65], Angulogerina angulosa is associated with larger grain size sediments and the influence of bottom currents in the eastern region of the South Atlantic, between $400 \mathrm{~m}$ and $700 \mathrm{~m}$, and at more than $900 \mathrm{~m}$ depth. On the upper slope of Potiguar Basin, Angulogerina occidentalis, s.l., and on the middle slope (400 m), Cribrostomoides subglobosus and Hoeglundina elegans are probably responding to the broad influence of this current.

Epistominella spp. were especially abundant at $1000 \mathrm{~m}$, mainly occurring at surficial layers. According to Schnitker [66] and Lohmann [67], the Epistominella exigua community is restricted to areas under the influence of the North Atlantic Deep Water in the Atlantic. E. exigua is a cosmopolitan species that feed opportunistically on phytodetritus deposited seasonally on the seafloor and is usually associated with elevated oxygen concentrations [68-70]. Comparing phytodetritus assemblages with other assemblages from his study area, Gooday [71] found relatively few species (11-15), low diversity, and high dominance values at the phytodetritus assemblages. In our study, the dominance was higher at the lower slope (surficial layer), and the diversity diminishes at the lower and middle slope $(1000 \mathrm{~m})$. Epistominella spp. dominate the superficial layers from the middle slope $(1000 \mathrm{~m})$, where organic matter, sedimentary phytoplankton chlorophyll, and phytodetritus content were higher. At the $1000 \mathrm{~m}$ isobath, Adercotryma glomeratum, Oridorsalis umbonatus, Alabaminella weddellensis and Globocassidulina subglobosa were also recorded to be associated with phytodetritus by Gooday [71]. Most of them were also associated with sedimentary phytodetritus at Santos Basin, Brazil [72]. The middle slope $(1000 \mathrm{~m})$ is the region most influenced by primary production (chlorophyll and phytodetritus) within the study area.

When comparing the data obtained in the surface and integrated layers, we observe the prevalence of the same patterns. The community structure of the integrated strata followed the same trend as the surficial layer. In both, there was a tendency for the density and diversity to decline towards the deeper slope areas. The highest density occurred in the upper slope, and the most notable diversity occurred in the middle slope $(400 \mathrm{~m})$. They also present the same patterns of dominance and equitability. Minor changes could be observed among the most abundant species of the shallow region (upper and middle slope $400 \mathrm{~m}$ ) when comparing the integrated and the surficial layer. At the deeper stations, only the order of the most abundant species changed.

The data obtained in this study suggest that the foraminifera found in the surface layer accurately represents the environment, allowing reliable environmental characterization. The integration of foraminifers from the subsurface layer did not change the observed patterns. So, it is not necessary to study the double of the sedimentary volume. The increment of species when analyzing $200 \mathrm{~cm}^{3}$ was 53 species, representing $12 \%$ of the recorded species. None occurred at a density greater than 20 individuals $/ 100 \mathrm{~cm}^{3}$, they are rare species with a relative frequency lower than $2 \%$ in the subsurface layer. Most analyses are based on species with more than $2 \%$ relative frequency, which means that they will be excluded from these analyses. Licari and Mackensen [19] concluded that the foraminiferal fauna of the surface layer $(0-1 \mathrm{~cm})$ coincided with what they found in the total column $(0-5 \mathrm{~cm})$. Even though observed minor differences in species composition and distribution, the authors concluded that most of the qualitative ecological information (absence/presence of species and geographic occurrences) is obtained by analyzing only the upper centimeter. The present study corroborates the main results of these authors.

\section{Conclusions}

The three main foraminiferal assemblages identified along the continental slope of the Potiguar Basin represented the upper slope (150 $\mathrm{m}$ isobath), the middle slope (400 $\mathrm{m}$ isobath if the subsurface layer is analyzed, or including the $1000 \mathrm{~m}$ isobath when surface and integrated layers are evaluated), and the lower slope (1000 m and $2000 \mathrm{~m}$ isobaths if the subsurface is analyzed, and only the $2000 \mathrm{~m}$ isobath when surface and integrated layers are evaluated). 
The assemblages are controlled by bathymetry, sediment (grain size, organic matter, chlorophyll, and phytodetritus content), and by the water masses properties (oxygen, temperature, and nutrients), together with bottom geomorphology and currents.

Density and diversity trends showed higher values in the upper and middle slope $(400 \mathrm{~m})$ and lower values in the middle $(1000 \mathrm{~m})$ and lower slope, corroborating published data from other regions. The surface layer presented more abundance of foraminifera and more diverse assemblages than the subsurface layer.

Angulogerina occidentalis, s.l., Adercotryma glomeratum, Cribrostomoides subglobosus and Hoeglundina elegans indicate slope areas under the influence of stronger bottom currents (150 $\mathrm{m}$ and $400 \mathrm{~m}$ ). Trifarina bradyi indicates anoxic or dysoxic zones as occurs in many other regions of the world.

Our results demonstrated that the efforts made to process and analyze samples from the surficial layer prove adequate for effective environmental characterization of the slope region based on foraminiferal assemblages in the area studied. The incorporation of foraminifers from the subsurface $(2-5 \mathrm{~cm})$ sediment layer did not change the pattern observed at the surficial layer. Our study at the slope of the western South Atlantic had the same effectiveness founded by Licari and Mackensen [19], studying the same organisms from the surface $(0-1 \mathrm{~cm})$ layer at the eastern South Atlantic.

Nevertheless, when time and technical resources are available, it is always interesting to obtain more information, especially from regions with little available data. Foraminifers of the surficial layer are sufficient bioindicators of the leading environmental conditions. However, the study of deeper layers adds knowledge about the ecology of these organisms and provides additional information about the environment, allowing for the registration of some species that are only found in the subsurface layer of the area.

Supplementary Materials: The following are available online at https:/ /www.mdpi.com/article/10 $.3390 / w 13131863 / s 1$, Supplementary Figure S1: Abiotic data of continental slope Potiguar Basin. (a) Temperature $\left({ }^{\circ} \mathrm{C}\right) ;($ b) Oxygen $(\mathrm{mg} / \mathrm{L}) ;(\mathrm{c}) \mathrm{pH}$; (d) Sedimentary organic matter $(\%)$; (e) Chlorophylla ( $\mu \mathrm{g} / \mathrm{L}) ;(\mathrm{f})$ Pheophytin-a ( $\mu \mathrm{g} / \mathrm{L})$. Supplementary Table S1. List of recorded species on the continental slope of the Potiguar Basin, with their original designations. Genus or morphotypes with undefined species names are absent. Supplementary Table S2. Values of the ecological indices of foraminifera assemblages from the continental slope Potiguar Basin. Supplementary Table S3. Relative frequency of species $(\geq 2 \%)$ from studied layers in the continental slope of the Potiguar Basin. Supplementary Table S4. Indicator species of the surface layer of the Potiguar Basin.

Author Contributions: Conceptualization, L.C.d.C.S.-R. and S.T.D.; data curation, L.C.d.C.S.-R., V.T. and S.W.; formal analysis, L.C.d.C.S.-R. and A.T.B.G.; funding acquisition, S.T.D.; Investigation, L.C.d.C.S.-R., S.T.D., V.T. and S.W.; methodology, L.C.d.C.S.-R. and A.T.B.G.; project administration, S.T.D.; software, L.C.d.C.S.-R. and A.T.B.G.; supervision, S.T.D.; validation, L.C.d.C.S.-R., S.T.D., V.T., S.W. and A.T.B.G.; visualization, L.C.d.C.S.-R.; Writing—original draft, L.C.d.C.S.-R., S.T.D., V.T. and A.T.B.G.; writing - review \& editing, L.C.d.C.S.-R., S.T.D., V.T. and A.T.B.G. All authors have read and agreed to the published version of the manuscript.

Funding: This work was carried out with support from Conselho Nacional de Desenvolvimento Científico e Tecnológico (CNPq).

Institutional Review Board Statement: Not applicable.

Informed Consent Statement: Not applicable.

Data Availability Statement: The data presented in this study are available upon request to the project administration's author. Most data are not yet publicly known; they are subject to access restrictions and might be made available only with authorization from PETROBRAS S/A, the data holder.

Acknowledgments: The authors would like to thank the environmental analyst Márcia de França Rocha, and Breno Frias Dutra, who worked at the Unidade de Operações do Rio Grande do Norte e Ceará, organizing and coordinating the sampling campaigns. We are grateful for the samples to PETROBRAS-Petróleo Brasileiro S/A; these samples were collected under the Coastal and Oceanic Environmental Monitoring Program-Project of Environmental Characterization of the Continental 
Slope of the Potiguar Basin. The first author thanks Maria Angélica Haddad for her supervision during her master's degree studies. The authors thank Fabián G. Tricárico from the Scanning Electronic Microscopy Service of the MACN/CONICET, Buenos Aires (Argentina). We thank to Centro de Microscopia Eletrônica (CME/UFPR) for the analysis carried out. Thanks to the Laboratório de Foraminíferos e Micropaleontologia Ambiental (LaFMA) colleagues: Daniel V. Pupo; Elis R. Ribas; Erika Kiemo; Helenita C. D. Forcelini; Leticia Woss; Manuela Santana; Thaise Ricardo, who assisted in processing surface samples. We thank Clauber R. da Costa for making the maps. We thank the Laboratório de Geologia e Geofísica Marinha e Monitoramento Ambiental GGEMMA/UFRN, Laboratório de Análise Ambiental, Museu Câmara Cascudo (LAA-MCC/UFRN), Laboratório de Geografia Física (LabGeoFis/UFRN) for the sedimentary data, and Grupo de Pesquisa: Espectroanalítica, Automação e Ambiental GPEAA/UFF) for the nutrient data. The authors also want to thank the Museu de Ciências Naturais-SCB/UFPR for housing the Foraminifera Collection. Finally, we are grateful for the criticism and contribution of the two anonymous reviewers.

Conflicts of Interest: The authors declare no conflict of interest.

\section{Appendix A. Plates}

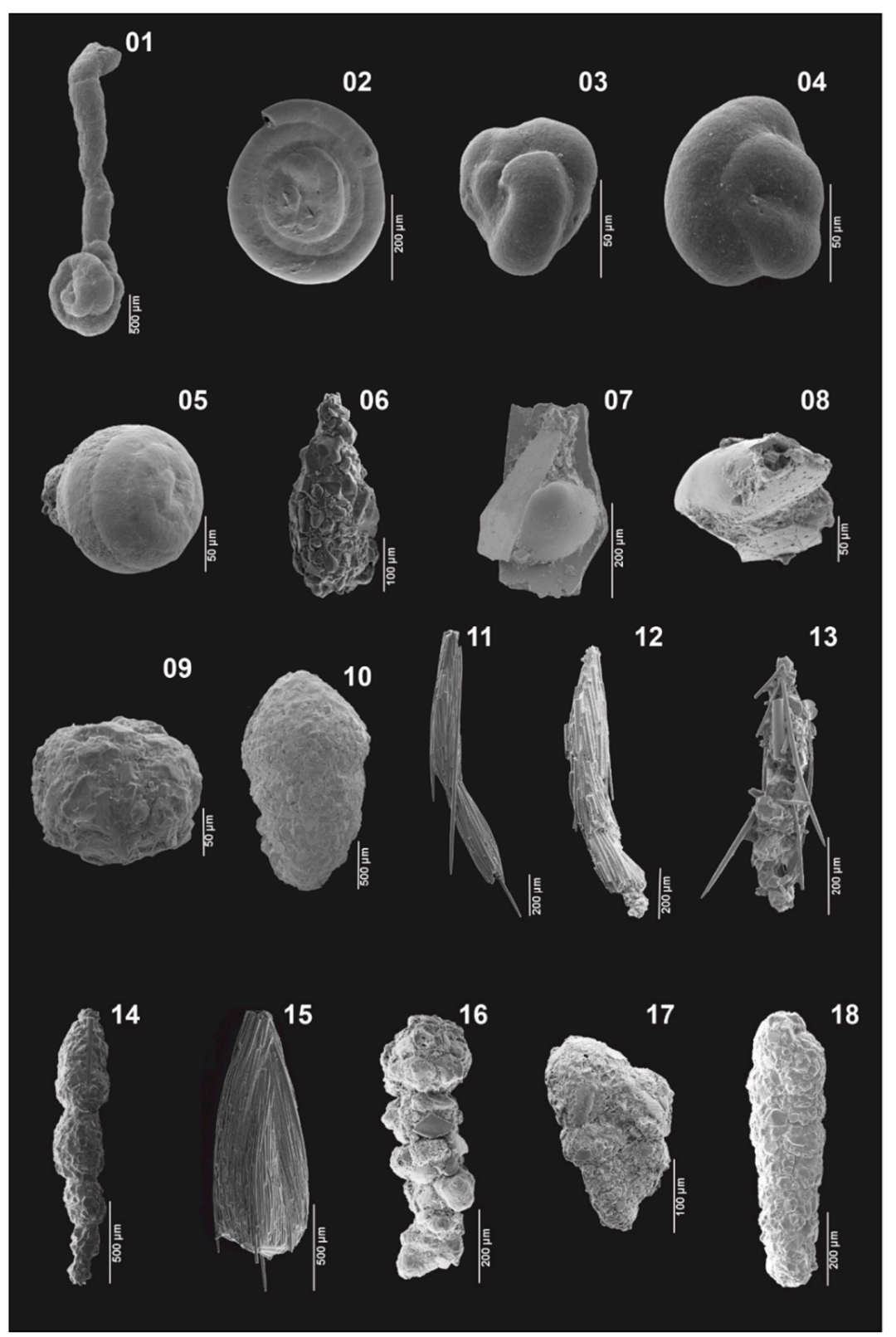

Figure A1. Plate I: 1—Lituotuba lituiformis (Brady, 1879), side view; 2-Glomospira gordialis (Jones \& 
Parker, 1860), side view; 3,4-Glomospira sp. 1, side views; 5-Repmanina charoides (Jones \& Parker, 1860), side view; 6-Lagenammina difflugiformis (Brady, 1879), side view; 7,8 Lagenammina? sp. 2: 7, side view; 8 apertural view; 9-Psammosphaera fusca Schulze, 1875, s.l., side view; 10Liebusella soldanii (Jones \& Parker, 1860), side view; 11,12-Reophax spiculifer Brady, 1879, side views; 13-Reophax hispidulus Cushman, 1920, side view; 14-Nodulina dentaliniformis (Brady, 1881), side view; 15-Nouria harrisii Heron-Allen \& Earland, 1914, side view; 16,17 Bigenerina textularioidea (Goës, 1894): 16 side view—adult specimen; 17 side view—juvenile specimen with only the biserial stage; 18-Morulaeplecta bulbosa Höglund, 1947, side view.

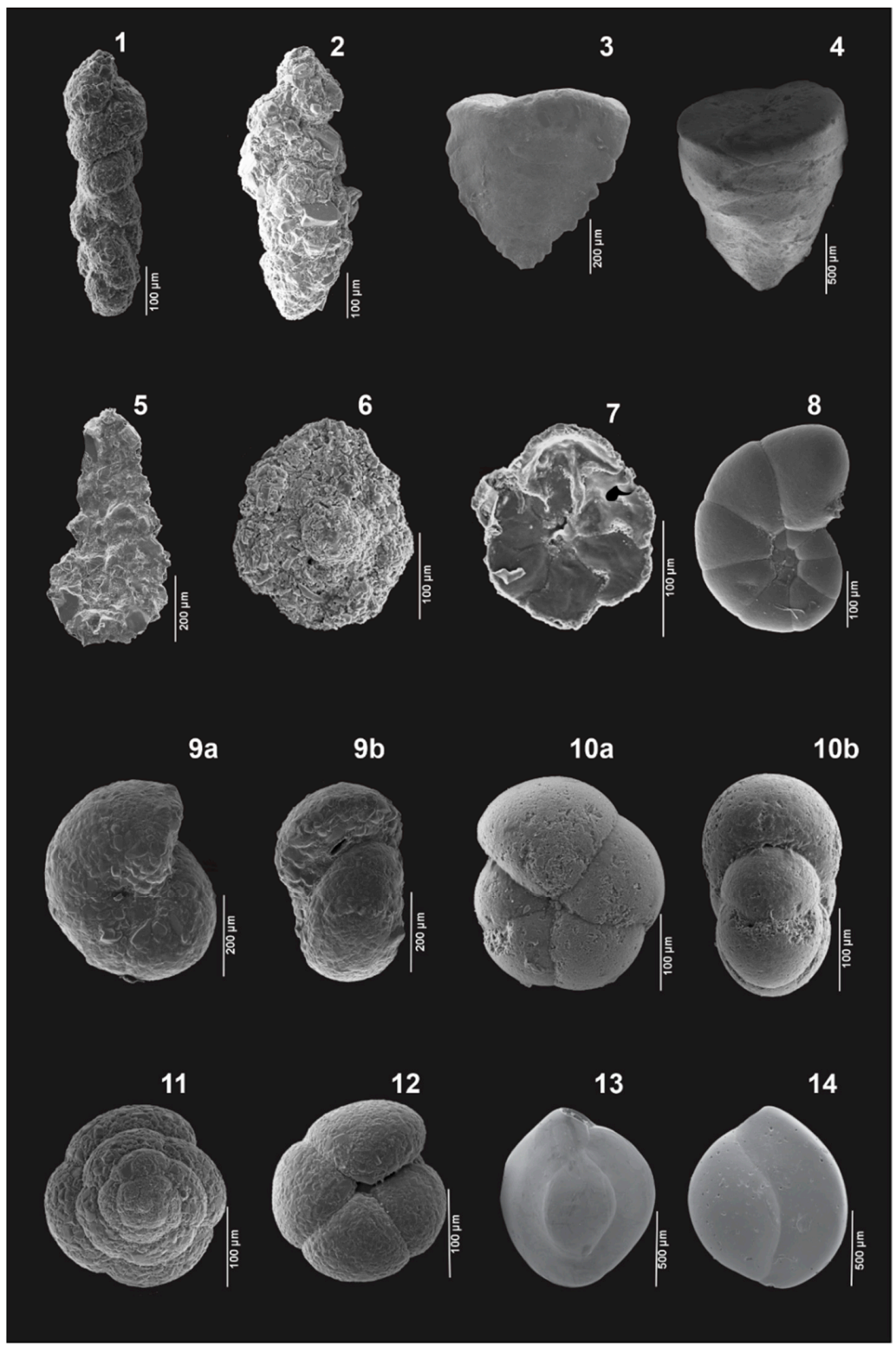

Figure A2. Plate II: 1-Karrerulina conversa (Grzybowski, 1901), side view; 2-Karrerulina sp. A, side view; 3-Textularia truncata Höglund, 1947, side view; 4-Textulariella barrettii (Jones \& Parker, 1876), side view; 5-Eratidus foliaceus (Brady, 1881), side view; 6,7-Trochamminidae indet. 6: 6 spiral view; 7-umbilical view; 8-Veleroninoides wiesneri (Parr, 1950), side view; 9a,b-Recurvoides contortus Earland, 1934: a—side view; b-apertural profile; 10a,b-Haplophragmoides neobradyi Uchio, 1960: a—side view; b-apertural profile; 11,12-Paratrochammina brasiliensis (Brönnimann \& Beurlen, 1977): 11—spiral view; 12-umbilical view; 13,14-Quinqueloculina sp. 3: 13-side view (4 chambers); 14 - side view (3 chambers). 


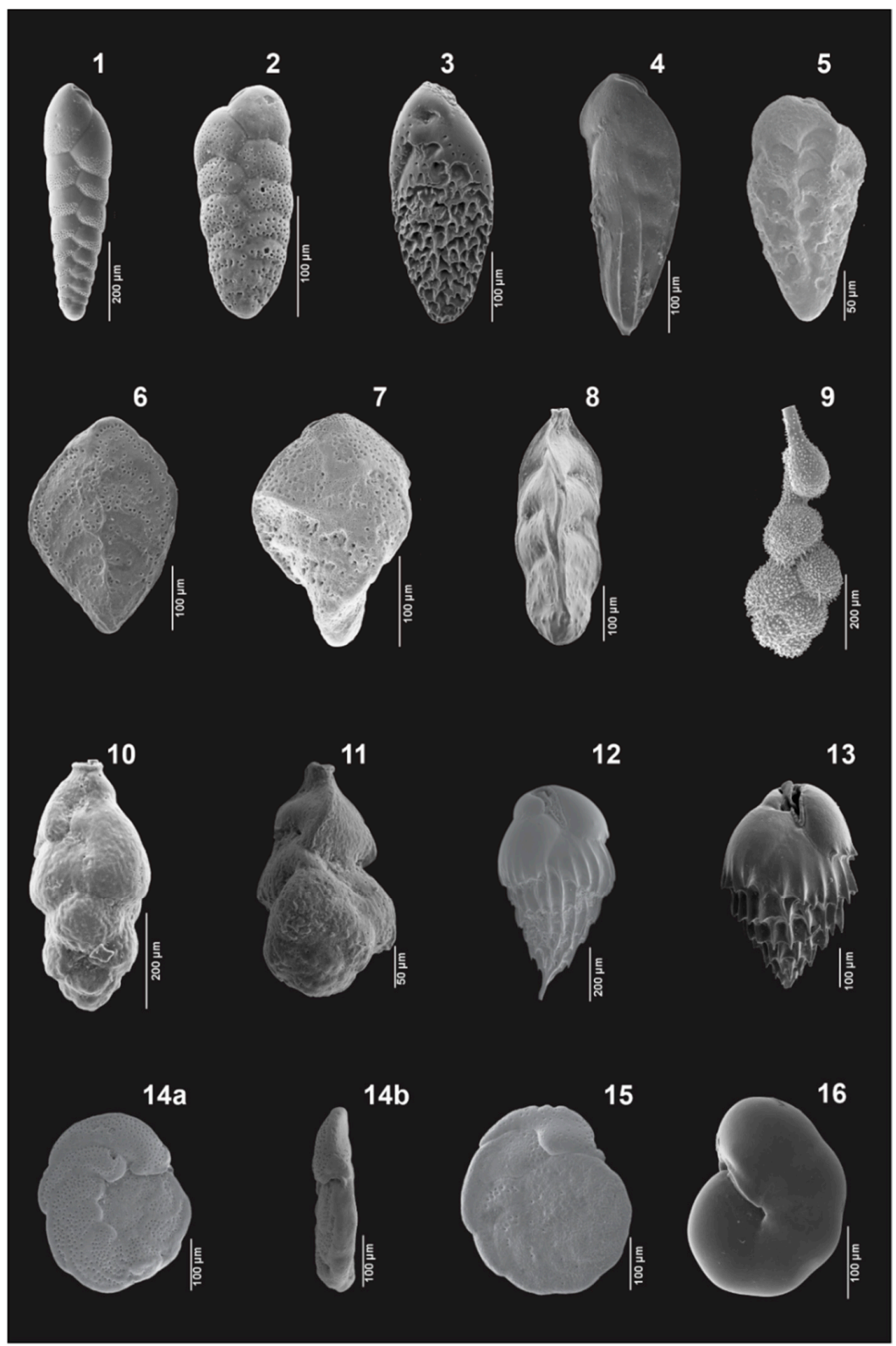

Figure A3. Plate III: 1-Bolivinellina translucens (Phleger \& Parker, 1951), side view; 2Bolivina vaughani Natland, 1938, side view; 3-Bolivina albatrossi Cushman, 1922, side view; 4 Bolivina fragilis Phleger \& Parker, 1951, side view; 5-Bolivina pseudoplicata Heron-Allen \& Earland, 1930, side view; 6-Bolivina goesii Cushman, 1922, side view; 7-Sigmavirgulina tortuosa (Brady, 1881), side view; 8-Trifarina bradyi Cushman, 1923, side view; 9-Uvigerina ampullacea Brady, 1884, side view; 10,11-Angulogerina occidentalis (Cushman, 1923), s.l., side views; 12,13-Bulimina striata d'Orbigny in Guérin-Méneville, 1832, side views; 14a,b,15-Planulina ariminensis d'Orbigny, 1826: 14a-umbilical view; 14b—apertural profile; 15—spiral view; 16—Pullenia aff. subcarinata (d'Orbigny, 1839), side view. 


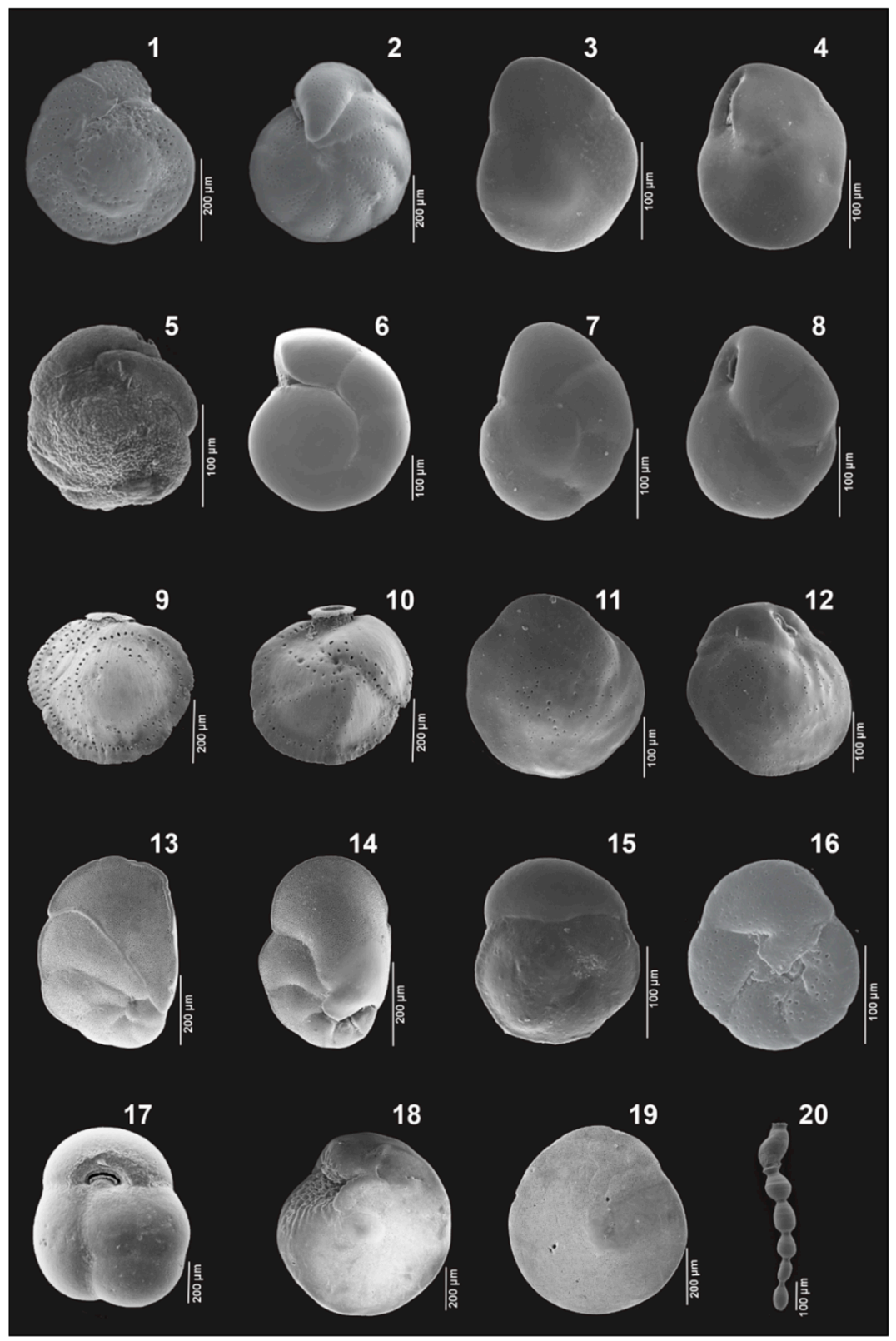

Figure A4. Plate IV: 1,2-Cibicidoides mundulus (Brady, Parker \& Jones, 1888): 1-spiral view; 2-umbilical view; 3,4-Epistominella exigua (Brady, 1884): 3-spiral view; 4-umbilical view; 5-Nuttallides umbonifer (Cushman, 1933), spiral view; 6-Gyroidina sp. 2, spiral view; 7,8Epistominella sp. 1, 7-spiral view; 8-umbilical view; 9,10-Siphonina bradyana Cushman, 1927, 9-spiral view; 10-umbilical view; 11,12-Cassidulina curvata Phleger \& Parker, 1951: 11—side view; 12-side view showing the aperture; 13,14-Cancris auricula (Fichtel \& Moll, 1798): 13spiral view; 14-umbilical view; 15,16-Gavelinopsis sp. 1: 15—spiral view; 16-umbilical view; 17-Sphaeroidina bulloides d'Orbigny in Deshayes, 1828, apertural view; 18,19-Amphistegina gibbosa d'Orbigny, 1839, 18 — side view showing the aperture; 19—side view; 20-Resigella moniliformis (Resig, 1982), side view.

\section{References}

1. Alve, E. Benthic Foraminiferal Responses to Estuarine Pollution: A Review. J. Foraminifer. Res. 1995, 25, 190-203. [CrossRef]

2. Armynot du Châtelet, E.; Gebhardt, K.; Langer, M.R. Coastal Pollution Monitoring: Foraminifera as Tracers of Environmental Perturbation in the Port of Boulogne-Sur-Mer (Northern France). Neues Jahrb. Geol. Palaontol. Abh. 2011, 262, 91-116. [CrossRef]

3. Bouchet, V.M.P.; Alve, E.; Rygg, B.; Telford, R.J. Benthic Foraminifera Provide a Promising Tool for Ecological Quality Assessment of Marine Waters. Ecol. Indic. 2012, 23, 66-75. [CrossRef] 
4. Martins, M.V.A.; Yamashita, C.; de Mello e Sousa, S.H.; Koutsoukos, E.A.M.; Disaró, S.T.; Debenay, J.P.; Duleba, W. Response of Benthic Foraminifera to Environmental Variability: Importance of Benthic Foraminifera in Monitoring Studies; Bachari Fouzia, H., Ed.; IntechOpen: London, UK, 2019; ISBN 978-1-83880-811-2.

5. Sousa, S.H.M.; Yamashita, C.; Semensatto, D.L.; Santarosa, A.C.A.; Iwai, F.S.; Omachi, C.Y.; Disaró, S.T.; Martins, M.V.A.; Barbosa, C.F.; Bonetti, C.H.C.; et al. Opportunities and Challenges in Incorporating Benthic Foraminifera in Marine and Coastal Environmental Biomonitoring of Soft Sediments: From Science to Regulation and Practice. J. Sediment. Environ. 2020, 5, $257-265$. [CrossRef]

6. Schönfeld, J.; Alve, E.; Geslin, E.; Jorissen, F.; Korsun, S.; Spezzaferri, S.; Abramovich, S.; Almogi-Labin, A.; Armynot du Chatelet, E.; Barras, C.; et al. The FOBIMO (FOraminiferal BIo-MOnitoring) Initiative-Towards a Standardised Protocol for Soft-Bottom Benthic Foraminiferal Monitoring Studies. Mar. Micropaleontol. 2012, 94-95, 1-13. [CrossRef]

7. Jorissen, F.J. Benthic foraminiferal microhabitats below the sediment-water interface. In Modern Foraminifera; Springer: Dordrecht, The Netherlands, 1999; pp. 161-179.

8. Linke, P.; Lutze, G.F. Microhabitat Preferences of Benthic Foraminifera-a Static Concept or a Dynamic Adaptation to Optimize Food Acquisition? Mar. Micropaleontol. 1993, 20, 215-234. [CrossRef]

9. Corliss, B.H. Morphology and Microhabitat Preferences of Benthic Foraminifera from the Northwest Atlantic Ocean. Mar. Micropaleontol. 1991, 17, 195-236. [CrossRef]

10. Gooday, A.J. Meiofaunal Foraminiferans from the Bathyal Porcupine Seabight (Northeast Atlantic): Size Structure, Standing Stock, Taxonomic Composition, Species Diversity and Vertical Distribution in the Sediment. Deep Sea Res. Part A Oceanogr. Res. Pap. 1986, 33. [CrossRef]

11. Fontanier, C.; Jorissen, F.J.; Chailloua, G.; David, C.; Anschutz, P.; Lafon, V. Seasonal and Interannual Variability of Benthic Foraminiferal Faunas at $550 \mathrm{~m}$ Depth in the Bay of Biscay. Deep Res. Part I Oceanogr. Res. Pap. 2003, 50, 457-494. [CrossRef]

12. Heinz, P.; Hemleben, C. Regional and Seasonal Variations of Recent Benthic Deep-Sea Foraminifera in the Arabian Sea. Deep Res. Part I Oceanogr. Res. Pap. 2003, 50, 435-447. [CrossRef]

13. Szarek, R.; Nomaki, H.; Kitazato, H. Living Deep-Sea Benthic Foraminifera from the Warm and Oxygen-Depleted Environment of the Sulu Sea. Deep Res. Part II Top. Stud. Oceanogr. 2007, 54, 145-176. [CrossRef]

14. Fontanier, C.; Jorissen, F.J.; Lansard, B.; Mouret, A.; Buscail, R.; Schmidt, S.; Kerhervé, P.; Buron, F.; Zaragosi, S.; Hunault, G.; et al. Live Foraminifera from the Open Slope between Grand Rhône and Petit Rhône Canyons (Gulf of Lions, NW Mediterranean). Deep Res. Part I Oceanogr. Res. Pap. 2008, 55, 1532-1553. [CrossRef]

15. Mojtahid, M.; Griveaud, C.; Fontanier, C.; Anschutz, P.; Jorissen, F.J. Les Foraminifères Benthiques Vivants Le Long d'un Transect Bathymétrique (140-4800m) Dans Le Golfe de Gascogne (Atlantique NE). Rev. Micropaleontol. 2010, 53, 139-162. [CrossRef]

16. Fontanier, C.; Metzger, E.; Waelbroeck, C.; Jouffreau, M.; Lefloch, N.; Jorissen, F.; Etcheber, H.; Bichon, S.; Chabaud, G.; Poirier, D.; et al. Live (Stained) Benthic Foraminifera off Walvis Bay, Namibia: A Deep-Sea Ecosystem under the Influence of Bottom Nepheloid Layers. J. Foraminifer. Res. 2013, 43, 55-71. [CrossRef]

17. Fontanier, C.; Garnier, E.; Brandily, C.; Dennielou, B.; Bichon, S.; Gayet, N.; Eugene, T.; Rovere, M.; Grémare, A.; Deflandre, B. Living (Stained) Benthic Foraminifera from the Mozambique Channel (Eastern Africa): Exploring Ecology of Deep-Sea Unicellular Meiofauna. Deep Res. Part I Oceanogr. Res. Pap. 2016, 115, 159-174. [CrossRef]

18. Singh, D.P.; Saraswat, R.; Kaithwar, A. Changes in Standing Stock and Vertical Distribution of Benthic Foraminifera along a Depth Gradient (58-2750 m) in the Southeastern Arabian Sea. Mar. Biodivers. 2018, 48, 73-88. [CrossRef]

19. Licari, L.; Mackensen, A. Benthic Foraminifera off West Africa $\left(1^{\circ} \mathrm{N}\right.$ to $\left.32^{\circ} \mathrm{S}\right)$ : Do Live Assemblages from the Topmost Sediment Reliably Record Environmental Variability? Mar. Micropaleontol. 2005, 55, 205-233. [CrossRef]

20. Almeida, N.M.; Vital, H.; Gomes, M.P. Morphology of Submarine Canyons along the Continental Margin of the Potiguar Basin, NE Brazil. Mar. Pet. Geol. 2015, 68, 307-324. [CrossRef]

21. Gomes, M.P.; Vital, H. Revisão Da Compartimentação Geomorfológica Da Plataforma Continental Norte Do Rio Grande Do Norte, Brasil. Rev. Bras. Geociênc. 2010, 40, 321-329. [CrossRef]

22. Stramma, L.; England, M. On the Water Masses and Mean Circulation of the South Atlantic Ocean. J. Geophys. Res. Ocean. 1999, 104, 20863-20883. [CrossRef]

23. Silveira, I.C.A.; Schmidt, A.C.K.; Campos, E.J.D.; Godoi, S.S.; Ikeda, Y. A Corrente Do Brasil Ao Largo Da Costa Leste Brasileira. Braz. J. Oceanogr. 2000, 48, 171-183. [CrossRef]

24. Marin, F.D.O. A Subcorrente Norte do Brasil Ao Largo da Costa do Nordeste. Master's Thesis, Universidade de São Paulo, São Paulo, Brazil, 2009.

25. Silveira, I.C.A.; Flierl, G.R. Eddy Formation in 2 1/2-Layer, Quasigeostrophic Jets. J. Phys. Oceanogr. 2002, 32, 729-745. [CrossRef]

26. Krelling, A.P.M. A Estrutura Vertical dos Vórtices da Corrente Norte do Brasil. Master's Thesis, Universidade Federal do Rio de Janeiro, Rio de Janeiro, Brazil, 2010.

27. Testa, V.; Bosence, D.W.J. Carbonate-Siliciclastic Sedimentation on a High-Energy, Ocean-Facing, Tropical Ramp, NE Brazil. Geol. Soc. Spec. Publ. 1998, 149, 55-71. [CrossRef]

28. Krelling, A.P.M.; Silveira, I.C.A.; Polito, P.S.; Gangopadhyay, A.; Martins, R.P.; Lima, J.A.M.; Marin, F.O. A Newly Observed Quasi-Stationary Subsurface Anticyclone of the North Brazil Undercurrent at $4^{\circ}$ S: The Potiguar Eddy. J. Geophys. Res. Ocean. 2020, 125, 1-16. [CrossRef]

29. Walton, W.R. Techniques for Recognition of Living Foraminifera. Contrib. Cushman Found. Foraminifer. Res. 1952, 3, 56-60. 
30. Folk, R.L. Petrology of Sedimentary Rocks; Hemphill Publishing Company: Austin, TX, USA, 1968; ISBN 0914696149.

31. Ellis, B.F.; Messina, A.R. Catalogue of Foraminifera; Micropaleontology Press, American Museum of Natural History: New York, NY, USA, 1940.

32. Loeblich, A.R.; Tappan, H. Foraminiferal Genera and Their Classification; Van Nostrand Reinhold Company: New York, NY, USA, 1987.

33. Loeblich, A.R.; Tappan, H. Foraminifera of the Sahul Shelf and Timor Sea; Special Publication No. 31; Cushman Foundation for Foraminiferal Research: Lawrence, KS, USA, 1994.

34. Hottinger, L.; Halicz, E.; Reiss, Z. Recent Foraminifera from the Gulf of Aqaba, Red Sea; Slovenska Akademija Znanosti in Umetnosti: Ljubljana, Slovenia, 1993.

35. Kaminski, M.A. The Year 2000 Classification of the agglutinated foraminifera. In Proceedings of the Sixth International Workshop on Agglutinated Foraminifera, Prague, Czech Republic, 1-7 September 2001; Bubík, M., Kaminski, M.A., Eds.; Grzybowski Foundation Special Publication, 2004; Volume 8, pp. 237-255. Available online: http://gf.tmsoc.org/Documents/Library/2000 .pdf (accessed on 10 December 2020).

36. Hayward, B.W.; Grenfell, H.R.; Sabaa, A.T.; Neil, H.; Buzas, M.A. Recent New Zealand Deep-Water Benthic Foraminifera: Taxonomy, Ecologic Distribution, Biogeography, and Use in Paleoenvironmental Assessment; GNS Science: Lower Hutt, New Zealand, 2010; ISBN 9780478197778 (pbk.).

37. Debenay, J.P. A Guide to 1000 Foraminifera from Southwestern Pacific New Caledonia; French National Museum Natural History: Marseille, France, 2012.

38. Kaminski, M.A.; Cetean, C.G. A Catalogue of Agglutinated Foraminiferal Genera. Unpublished.

39. Efron, B. Bootstrap Methods: Another Look at the Jackknife. Ann. Stat. 1979, 7, 1-26. [CrossRef]

40. Magurran, A.E. Medindo a Diversidade Biológica; Editora UFPR: Curitiba, Brazil, 2013; Volume 1, ISBN 9788573352788.

41. Chao, A.; Gotelli, N.J.; Hsieh, T.C.; Sander, E.L.; Ma, K.H.; Colwell, R.K.; Ellison, A.M. Rarefaction and Extrapolation with Hill Numbers: A Framework for Sampling and Estimation in Species Diversity Studies. Ecol. Monogr. 2014, 84, 45-67. [CrossRef]

42. R Core Team R. A Language and Environment for Statistical Computing; R Foundation for Statistical Computing: Vienna, Austria, 2018.

43. Hsieh, T.C.; Ma, K.H.; Chao, A. INEXT: An R Package for Rarefaction and Extrapolation of Species Diversity (Hill Numbers). Methods Ecol. Evol. 2016, 7, 1451-1456. [CrossRef]

44. Clarke, K. Non-Parametric Multivariate Analyses of Changes in Community Structure. Aust. J. Ecol. 1993, 18, 117-143. [CrossRef]

45. Oksanen, A.J.; Blanchet, F.G.; Friendly, M.; Kindt, R.; Legendre, P.; Mcglinn, D.; Minchin, P.R.; Hara, R.B.O.; Simpson, G.L.; Solymos, P.; et al. Vegan: Community Ecology Package 2018. Available online: https://cran.r-project.org/web/packages/vegan/ index.html (accessed on 10 February 2021).

46. Salazar, G. EcolUtils R Package 2021. Available online: https:/ / github.com/GuillemSalazar/EcolUtils (accessed on 10 February 2021).

47. XLSTAT Data Analysis and Statistical Solution for Microsoft Excel 2016. Available online: https://www.xlstat.com/en/ (accessed on 20 April 2021).

48. Dufrene, M.; Legendre, P. Species Assemblages and Indicator Species: The Need for a Flexible Assymmetrical Aproach. Ecol. Monogr. 1997, 67, 345-366. [CrossRef]

49. Hammer, Ø.; Harper, D.A.T.; Ryan, P.D. Past: Paleontological Statistics Software Package for Education and Data Analysis. Palaeontol. Electron. 2001, 4, 1-9.

50. Vital, H.; Gomes, M.P.; Tabosa, W.F.; Frazão, E.P.; Santos, C.L.A.; Plácido Júnior, J.S. Characterization of the Brazilian Continental Shelf Adjacent to Rio Grande Do Norte State, Ne Brazil. Braz. J. Oceanogr. 2010, 58, 43-54. [CrossRef]

51. Buzas, M.A.; Hayek, L.-A.C.; Jett, J.A.; Reed, S.A. Pulsating Patches History and Analyses of Spatial, Seasonal, and Yearly Distribution of Living Benthic Foraminifera; Smithsonian Institution Scholarly Press: Washington, DC, USA, 2015.

52. Schmiedl, G.; Mackensen, A.; Müller, P.J. Recent Benthic Foraminifera from the Eastern South Atlantic Ocean: Dependence on Food Supply and Water Masses. Mar. Micropaleontol. 1997, 32, 249-287. [CrossRef]

53. Hayward, B.W.; Grenfell, H.R.; Sabaa, A.T.; Neil, H.L. Factors Influencing the Distribution of Subantarctic Deep-Sea Benthic Foraminifera, Campbell and Bounty Plateaux, New Zealand. Mar. Micropaleontol. 2007, 62, 141-166. [CrossRef]

54. Burone, L.; Sousa, S.H.M.; de Mahiques, M.M.; Valente, P.; Ciotti, A.; Yamashita, C. Benthic Foraminiferal Distribution on the Southeastern Brazilian Shelf and Upper Slope. Mar. Biol. 2011, 158, 159-179. [CrossRef]

55. Phipps, M.; Jorissen, F.; Pusceddu, A.; Bianchelli, S.; De Stigter, H. Live Benthic Foraminiferal Faunas along a Bathymetrical Transect (282-4987 M) on the Portuguese Margin (Ne Atlantic). J. Foraminifer. Res. 2012, 42, 66-81. [CrossRef]

56. Fiorini, F. Recent Benthic Foraminifera from the Caribbean Continental Slope and Shelf off West of Colombia. J. S. Am. Earth Sci. 2015, 60, 117-128. [CrossRef]

57. Bernhard, J.M. Distinguishing Live from Dead Foraminifera: Methods Review and Proper Applications. Micropaleontology 2000, $46,38-46$.

58. Sen Gupta, B.K.; Platon, E.; Bernhard, J.M.; Aharon, P. Foraminiferal Colonization of Hydrocarbon-Seep Bacterial Mats and Underlying Sediment, Gulf of Mexico Slope. J. Foraminifer. Res. 1997, 27, 292-300. [CrossRef]

59. Murray, J.W. Ecology and Applications of Benthic Foraminifera; Cambridge University Press: New York, NY, USA, 2006; ISBN 9780511535529. 
60. Buzas, M.A.; Gibson, T.G. Species Diversity: Benthonic Foraminifera in Western North Atlantic. Sci. New Ser. 1969, $163,72-75$. [CrossRef]

61. Gibson, T.G.; Buzas, M.A. Species Diversity: Patterns in Modern and Miocene Foraminifera of the Eastern Margin of North America. Bull. Geol. Soc. Am. 1973, 84, 217-238. [CrossRef]

62. Disaró, S.T.; Watanabe, S.; Totah, V.; Barbosa, V.P.; Koutsoukos, E.A.M.; Itice, I.; Pupo, D.V.; Chiaverini, A.P.; Foraminíferos, V.I.M. Relatório Integrador do Programa de Monitoramento Ambiental da Bacia Potiguar, IBAMA, Inédito (Acesso Restrito); Rocha, M., Ed.; IBAMA: Rio de Janeiro, Brazil, 2006; pp. 1-85.

63. Lavrado, H.P.; Disaró, S.T.; Esteves, A.M.; da Fonsêca-Genevois, V.; de Mello e Sousa, S.H.; Omena, E.P.; Paranhos, R.; Sallorenzo, I.; Veloso, V.G.; Ribeiro-Ferreira, V.P.; et al. Comunidades bentônicas dos substratos inconsolidados da plataforma e talude continental da Bacia de Campos: Uma visão integrada entre seus componentes e suas relações com o ambiente. In Ambiente Bentônico; Falcão, A.P.C., Lavrado, H., Eds.; Elsevier Habitats: Rio de Janeiro, Brazil, 2017; pp. $307-352$.

64. Krelling, A.P.M.; Gangopadhyay, A.; Silveira, I.; Vilela-Silva, F. Development of a Feature-Oriented Regional Modelling System for the North Brazil Undercurrent Region $\left(1^{\circ}-11^{\circ} \mathrm{S}\right)$ and Its Application to a Process Study on the Genesis of the Potiguar Eddy. $J$. Oper. Oceanogr. 2020,1-18. [CrossRef]

65. Mackensen, A.; Fütterer, D.K.; Grobe, H.; Schmiedl, G. Benthic Foraminiferal Assemblages from the Eastern South Atlantic Polar Front Region between $35^{\circ}$ and $57^{\circ}$ S: Distribution, Ecology and Fossilization Potential. Mar. Micropaleontol. 1993, $22,33-69$. [CrossRef]

66. Schnitker, D. West Atlantic Abyssal Circulation during the Past 120,000 Years. Nature 1974, 247, 385-387. [CrossRef]

67. Lohmann, G.P. Abyssal Benthonic Foraminifera as Hydrographic Indicators in the Western South Atlantic Ocean. J. Foraminifer. Res. 1978, 8, 6-34. [CrossRef]

68. Gooday, A.J. A Response by Benthic Foraminifera to the Deposition of Phytodetritus in the Deep Sea. Nature 1988, 332, 70-73. [CrossRef]

69. Gooday, A.J. Deep-Sea Benthic Foraminiferal Species Which Exploit Phytodetritus: Characteristic Features and Controls on Distribution. Mar. Micropaleontol. 1993, 22, 187-205. [CrossRef]

70. Kurbjeweit, F.; Schmiedl, G.; Schiebel, R.; Hemleben, C.; Pfannkuche, O.; Wallmann, K.; Schäfer, P. Distribution, Biomass and Diversity of Benthic Foraminifera in Relation to Sediment. Geochemistry in the Arabian Sea. Deep Sea Res. Part II Top. Stud. Oceanogr. 2000, 47, 2913-2955. [CrossRef]

71. Gooday, A.J. Epifaunal and Shallow Infaunal Foraminiferal Communities at Three Abyssal NE Atlantic Sites Subject to Differing Phytodetritus Input Regimes. Deep Res. Part I Oceanogr. Res. Pap. 1996, 43, 1395-1421. [CrossRef]

72. Disaró, S.T.; Aluizio, R.; Ribas, E.R.; Pupo, D.V.; Tellez, I.R.; Watanabe, S.; Totah, V.I.; Koutsoukos, E.A.M. Foraminíferos Bentônicos na plataforma continental da Bacia de Campos. In Ambiente Bentônico: Caracterização Ambiental Regional da Bacia de Campos, Atlântico Sudoeste; Falcão, A.P.C., Lavrado, H.P., Eds.; Elsevier: Rio de Janeiro, Brazil, 2017; pp. 65-110. Available online: https:/ / www.sciencedirect.com/science/article/pii/B9788535272635500047?via\%3Dihub (accessed on 20 May 2021). 